\title{
Corporate Acquisitions and Financial Constraints
}

DOI:

10.1016/j.irfa.2015.05.007

\section{Document Version}

Accepted author manuscript

Link to publication record in Manchester Research Explorer

\section{Citation for published version (APA):}

Khatami, S. H., Marchica, M. T., \& Mura, R. (2015). Corporate Acquisitions and Financial Constraints. International Review of Financial Analysis, 4O(July 2015), 107-121. https://doi.org/10.1016/j.irfa.2015.05.007

\section{Published in:}

International Review of Financial Analysis

\section{Citing this paper}

Please note that where the full-text provided on Manchester Research Explorer is the Author Accepted Manuscript or Proof version this may differ from the final Published version. If citing, it is advised that you check and use the publisher's definitive version.

\section{General rights}

Copyright and moral rights for the publications made accessible in the Research Explorer are retained by the authors and/or other copyright owners and it is a condition of accessing publications that users recognise and abide by the legal requirements associated with these rights.

\section{Takedown policy}

If you believe that this document breaches copyright please refer to the University of Manchester's Takedown Procedures [http://man.ac.uk/04Y6Bo] or contact uml.scholarlycommunications@manchester.ac.uk providing relevant details, so we can investigate your claim.

\section{OPEN ACCESS}




\title{
Corporate Acquisitions and Financial Constraints
}

\author{
Seyed Hossein Khatami \\ Manchester Business School \\ University of Manchester \\ e-mail: seyedhossein.khatami@mbs.ac.uk \\ Maria-Teresa Marchica \\ Manchester Business School \\ University of Manchester \\ e-mail:maria.marchica@mbs.ac.uk \\ Roberto Mura* \\ Manchester Business School \\ University of Manchester \\ e-mail: roberto.mura@mbs.ac.uk
}

\begin{abstract}
Acknowledgments: We thank Brian Lucey (the Editor) and the anonymous referee, Mara Faccio, Rebekka Haller, Wei-Hsien Li, Raghavendra Rau, participants at the FMA 2013 Conference in Chicago, FMA Europe 2014 in Maastricht, and the seminar participants at Manchester Business School. We are also grateful to Stephen Cashmore for editorial help. Hossein Khatami gratefully acknowledges research funding from the European Community's Seventh Framework Programme FP7-PEOPLE-ITN-2008 under grant agreement number PITN-GA-2009-237984. * Corresponding author
\end{abstract}




\title{
Corporate Acquisitions and Financial Constraints
}

\begin{abstract}
Using a large sample of US acquisitions made between 1985 and 2013, we study the effect of financial constraints on acquisition gains and acquisition likelihood. Our findings show that financial constraints of target companies significantly increase acquisition premiums and abnormal returns for both parties. Our results further show that the presence of financial constraints in the target is one of the most important determinants of a takeover bid. This supports the idea that acquisitions may improve the ability of financially constrained companies to access capital through a better reallocation of resources within segments of the same company (e.g., internal capital market) or through better access to external markets. This would eventually benefit bidders too, as new capital would be invested in valuable growth opportunities that otherwise would expire unexercised.
\end{abstract}

JEL Classification: G32, G34

Keywords: financial constraints, M\&A, acquisition likelihood 


\section{Introduction}

We provide direct evidence of the role played by firms' financial constraints in M\&A activities. In particular, we document that the value created with an M\&A largely depends on the degree of financial constraints of target firms. We further show that the degree of financial constraints of target firms is a key predictor of the probability to receive a takeover bid.

Financially constrained firms typically have substantial unexploited growth opportunities, since their difficulty in accessing capital markets forces them to forego (or postpone) highly profitable investment opportunities (Almeida et al., 2004). This has the potential to make financially constrained firms very palatable takeover targets. In a highly influential paper, Hubbard and Palia (1999) examine a sample of 392 acquisitions between 1961 and 1970. Their tests strongly suggest that the formation of internal capital markets, post-merger, is the key driver of the observed bidder abnormal returns during the conglomerate merger wave in the 1960s. In particular, the highest bidder returns are reported in the case where financially unconstrained buyers acquire constrained target firms.

In a more recent paper Erel, Jang and Weisbach (2014) provide direct evidence that acquisitions actually relieve the financial constraints of target companies. They follow target firms post acquisition and provide direct evidence that following the acquisition, target firms lower their cash holdings, experience lower sensitivity of cash to cash flow, and report lower sensitivity of investment to cash flow, and ultimately increase the quantity of their investments.

In this paper we extend the previous literature in a number of ways. First, we test the role of financial constraints on M\&A activity on a very recent sample of data using a very comprehensive set of definitions of financial constraints. To perform our tests, we use a large sample of acquisition announcements $(3,146)$ made in the US market between 1985 and 2013, where both bidder and target are publicly listed companies and the transactions involve more than $50 \%$ of the target. We compute the degree of financial constraints of both bidders and targets based on several of the most widely used measures of financial constraints in the literature: 1) Composite I \& II indices as proposed by Campello and Chen (2010); 2) the payout ratio (e.g. Fazzari, Hubbard and Petersen, 1988); 3) Kaplan and Zingales (KZ) index (Lamont, Polk, and Saa-Requejo, 2001); and 4) Hadlock and Pierce (HP) index (Hadlock and Pierce, 2010).

Second, we provide direct evidence that the level of financial constraints of target firms is an important source of value creation in M\&A. Our univariate tests show that, when 
acquisitions involve financially constrained targets, both bidders and target companies gain. This is robust to alternative measures of value. For instance, when we identify financially constrained targets using the Composite I index, the premium they receive is on average $16 \%$ higher had they been unconstrained. This may suggest that bidders are willing to pay higher premiums to take over financially constrained firms. Similarly, around the acquisition announcement, abnormal returns are about 5\% and $2.7 \%$ higher for targets and bidders respectively. Our multivariate analysis confirms that, other things being equal, the degree of financial constraints of target companies is indeed an important determinant of the value created in an M\&A deal: a constrained target (based on Composite I index) attracts 19.37\% higher acquisition premium than an unconstrained target with a p-value of less than 0.0001 . This holds across all measures of financial constraints. On the contrary, we fail to find any significant impact of the degree of financial constraints of bidder companies on acquisition value, independently from the definitions of financial constraints and values we use. This is independent of whether the deals pertain to diversifying mergers or within-industry acquisitions and also independent of the time period in which the deal took place. We also perform a number of robustness tests based on propensity score matched samples in the attempt to attenuate potential endogeneity concerns. For instance, certain bidders' characteristics my affect at the same time the choice of the (constrained or constrained) target and the premium to pay to one or the other type of target. If this is the case, then our previous tests may be spurious as the results would be driven by bidder rather than target characteristics.. However, all results on the matched samples are in line with our baseline findings.

Third, we show that financial constraints are a key determinant of the probability to receive a takeover bid. To this end we employ a logit model using a sample of 81,533 firmyear observations between 1985 and 2013 (including 5,090 acquisition targets). Our baseline model is similar to those proposed by some of the most influential studies in this field (e.g. Ambrose and Megginson, 1992; Song and Walking, 1993; Comment and Schwert, 1995; Billett and Xue, 2007). We then augment this baseline model with our financial constraints variables. The logit regression results strongly suggest that a higher degree of financial constraints in a company significantly increases the probability that it will be subject to a takeover attempt. This impact is not only statistically significant, but also economically sizable. For instance, when we use Composite I index to define financial constraints, a $1 \%$ change in target financial constraints increases the likelihood of receiving takeover bids by 
more than $0.2 \%$. This is the largest effect among all variables included in the model. In fact, the average effect of all other control variables (in absolute value) is about $0.05 \%$. The marginal effect of financial constraints seems also sizeable if compared to the baseline probability of being a target company, about $6.66 \%$. We find similar results when we focus only on completed acquisitions. This is a very important result. This suggests that future studies that model the M\&A decision, should probably account for the level of financing constraints in the target firm to achieve better model fit.

Our results are related to previous findings on the role played by liquidity policy in acquisitions. For instance, Almeida, Campello and Hackbarth (2011) show that financially distressed firms, which suffer from liquidity mismanagement, are more subject to acquisition by liquid firms in their industries, focusing also on the effect of industry- and firm-level asset specificity. Our paper complements their findings since the focus here is on the financial constraints (which might co-exist with (lack of) good liquidity management, but they don't necessarily lead to distress), and their effects on the gains to the acquisition parties and the acquisition likelihood.

The evidence in our paper also complements the small but increasing literature on acquisitions of minority equity positions that represent a rather distinct organizational choice from M\&A activities (Ouimet, 2013). Studies in this area show that (along with other factors related to contractual incompleteness) financial constraints are important in the decision to acquire minority equity stakes (Fee, Hadlock and Thomas, 2006; Ouimet, 2013; Liao, 2014). Our focus is rather different since we study acquisitions of majority block positions (i.e. involving $50 \%$ or more equity stake). Moreover, differently from the above papers, we investigate the role of both bidder and target financing constraints in M\&As. Our results complement this literature as we show that also in the setting of M\&A transactions, financial constraints of target firms are important. More in particular, we show that target financial constraints play a major role in both value creation and likelihood to be associated with a majority acquisition.

The rest of this paper is structured as follows. In section 2, we describe our sample, the measures of financial constraint and our methodology. In section 3, we present our empirical tests and results, and discuss the implications of our findings. Section 4 concludes. 


\section{Data and Methodology}

We gather acquisition deals data from the Securities Data Company's (SDC) US Mergers and Acquisitions database. For our core sample (used for analysis of premiums and gains) we focus only on acquisition deals with public bidders and targets which were announced between 1985 and 2013. Accounting data are from the COMPUSTAT database. We further extract daily share prices from CRSP (Center for Research in Security Prices) database to calculate abnormal returns and premiums. To build two of the financial constraints measures we collect information on company bond and commercial paper ratings from COMPUSTAT Ratings files. Finally, we use data on business cycles from the National Bureau of Economic Research (NBER) Business Cycle Expansions and Contractions.

We exclude financial (SIC 6000-6999) and regulated utility (SIC 4909-4939) companies from our sample as acquisitions in these industries are highly regulated by government. We require both accounting and share price data to be available for bidders and targets for at least the year prior to the acquisition announcement. We further require that companies in our sample do not have any other acquisitions announced in a $(-63,+42)$ day period surrounding the acquisition announcement. ${ }^{1}$ All bidders are required to have less than $50 \%$ shares in their targets prior to acquisition, and seek more than 50\% of targets' ordinary shares following the takeover. We also exclude deals where the targets are bankrupt as we are interested in financially constrained rather than bankrupt companies. We also exclude those instances where the deal value is less than $\$ 1 \mathrm{~m}$ or $1 \%$ of the bidder's market capitalization 43 days prior to the announcement. The above requirements leave us with 3,146 acquisition announcements. $^{2}$

Our sample size is considerably larger for the second part of the analysis where we estimate the probability of takeover. This is because we have to include those non-financial and non-regulated companies that have never been subject to acquisition attempts. Further, at this stage we relax the inclusion criteria applied to targeted companies (that is, relative size of deal to bidder and availability of data for the acquirer). Therefore, the final sample comprises

\footnotetext{
${ }^{1}$ Schwert (1996) shows that the price run-up associated with a takeover (due to rumors and news) is mostly manifested after the 42nd day prior to the first bid. Our analysis is based on 11-day $(-5$ to +5$)$ cumulative abnormal returns (CARs) around the announcement day. We prefer to adopt a very conservative approach in requiring no other deals in the $(-63,+42)$ window. Untabulated results with less conservative restrictions are qualitatively similar to those reported in the paper.

${ }^{2}$ Note that in the analysis of cumulative abnormal returns to bidders (and/or targets) we further require bidders (and/or targets) to have at least 25 observations in the daily stock return data on CRSP during the estimation period, i.e. [-316,-43] days (2/3 of a year) prior to acquisition announcement.
} 
81,533 firm-year observations from the period 1985 to 2013 (5,090 target and 76,443 nontarget observations).

\subsection{Measures of Financial Constraints}

Since the seminal paper by Fazzari, Hubbard and Petersen (1988), literature has proposed several criteria to identify the level of financial constraints faced by firms. However, there is no general agreement on which measure is the best proxy. Some discrete measures (e.g., availability of bond/CP rating) are more prone than others to classification noise and they are available for only a limited number of companies. Other measures, e.g., dividends payout, size, age, focus only on a specific aspect of the broader concept of financial constraints (e.g. Fazzari et al., 1988; Schiantarelli, 1995; Guariglia, 2008). More recent reviews of financial constraints measures have questioned the reliability of some indices proposed in the literature, such as the Kaplan-Zingales (KZ) index and Whited-Wu (WW) index (Almeida et al., 2004; Hadlock and Pierce, 2010). ${ }^{3}$

To construct our main measures of financial constraints that try to minimize (at least) some of the limitations of the above criteria, we largely follow Campello and Chen (2010).

Composite I Index. As in Campello and Chen (2010), we sort the entire universe of firms in COMPUSTAT based on dividend payout ratio, size, interest coverage ratio, and the $K Z$ index separately. ${ }^{4}$ (Please see the Appendix that reports the definitions of each variable included in each financial constraints measure.) We then rank companies in quintiles and assign a score of 1 to 5 to each distribution. Further, we assign a score of 0 (5) to those companies without (with) commercial paper rating and bond rating separately. Contrary to Campello and Chen (2010), we require a company to have at least three of the above six criteria available to prevent our sample from decreasing dramatically. We then assign an overall score to each firm based on the weighted average ranks (weights are based on the number of available components). The lower the overall score the higher the financial constraints. Therefore, to make the interpretation of results more intuitive, we transform the overall ranking as "6overall ranking", so that the higher the overall ranking, the more constrained the company. Once we have computed the overall ranking for each company each year, we assign firms in

\footnotetext{
${ }^{3}$ Using their measure of cash flow sensitivity of cash, Almeida et al. (2004) note that "the KZ index generates constrained/unconstrained firm assignments that are mostly negatively correlated with those of the other [...] classification criteria". Further, Hadlock and Pierce (2010) provide evidence that "the only truly new variable from the WW index that offers marginal explanatory power" over the KZ index is firm size.

${ }^{4}$ Classifying companies based on the reduced sample of M\&A deals would introduce a significant bias as companies involved in M\&A may have systematically different characteristics from the entire population.
} 
the top (bottom) three deciles of the overall rank distribution to the financially constrained (unconstrained) group.

Composite II index. The construction of this measure is similar to the previous one, except that rankings of companies are based on dividend payout ratio, interest coverage ratio, availability of commercial paper rating and availability of bond rating only. This second composite index thus excludes both the $K Z$ index and the size factors. The reason for excluding both $K Z$ index and size is that the $\mathrm{KZ}$ measure occasionally yields a classification of companies opposite to that provided by other measures (Almeida et al., 2004); while company size is often used as a separate control variable in multivariate analyses. As in the previous measure, we assign firms in the top (bottom) three deciles of the overall rank distribution to the financially constrained (unconstrained) group.

The correlations between our measures and those of Campello and Chen (2010) are close to one, suggesting that our procedure does not create any distortion in the firms' classification.

For comparison purposes we use and report also three other criteria of financial constraints: the dividend payout ratio, the KZ index and the Hadlock and Pierce (2010) index. In the Appendix we report a detailed description of these alternative financial constraints measures.

For brevity, we use the following acronyms to indicate different classes of acquisitions: " $T$ " and " $B$ " stand for target and bidder respectively. " $F C$ " and " $N F C$ " stand for "Financially Constrained" and "Not Financially Constrained" respectively. For each measure of financial constraints, we define a company as FC (NFC) if it belongs to the top (bottom) tertile of each measure distribution.

Table 1 shows the number of observations that are classified as constrained (unconstrained) for the two parties of targets and bidders. A large number of target companies are classified as constrained across all our classifications of financial constraints. Further, most of the acquisitions seem to involve unconstrained bidders. This may suggest that companies with better access to capital and possibly less internal investment opportunities search for growth options externally.

Please insert Table 1 here 


\subsection{Premiums and Abnormal Returns}

In line with previous studies in the M\&A literature, we analyze the gains from acquisitions to targets on both acquisition premiums and target cumulated percentage abnormal returns (CARs) around the acquisition announcement date; and the gains from acquisitions to bidders on both bidder percentage and dollar abnormal returns.

We follow Officer (2003) in defining acquisition premium as "the aggregate amount of each form of payment offered to target shareholders (cash, equity, debt, etc.)" divided by the market value of the target (or the sought stake) 43 days prior to the bid announcement if the result falls between 0 and 2 - and if it does not, as "the final (and then the initial) price per share of target stock offered by the bidder" divided by the target share price 43 days before the announcement if this number falls between 0 and 2 . The premium is missing if neither of the above conditions is met.

We compute 11-day CARs from five days before to five days after acquisition announcements, and omit observations for which there are no share price data (for bidder or target) on CRSP either before or after the announcement date inside the 11-day windows. The estimation period in our event study is the $[-316,-43]$ day period (2/3 of a year) with respect to the acquisition announcement date. Schwert (1996) shows that the price run-up associated with a takeover might start from 42 days prior to the first bid; hence our estimation period does not include the $[-42,-1]$ days prior to the deal. We base our calculation of the normal (or expected) returns alternatively on the market model, CAPM and FF-3-factor model. When analyzing the returns, we require companies to have at least 25 daily stock returns available on CRSP during the estimation period. ${ }^{5}$ Results are very similar across the three models. We therefore report only the results for the FF-3-factor model.

Further, we estimate the bidder dollar value abnormal returns in line with Malatesta (1983) and Matsusaka (1993); that is, we calculate the percentage abnormal returns times the market values of the companies six days before the dates of announcements.

\section{Results: Effect of Financial Constraints on Gains from Acquisition}

\footnotetext{
${ }^{5}$ Several studies use also the 25 portfolios of Fama and French to calculate the normal returns. The minimum number of daily stock return observations during the estimation period required to implement this strategy should be higher (at least around 100) for the normal returns to be less sensitive to the estimation period. This would decrease our sample size dramatically. Therefore, this approach is not used in the paper.
} 
We analyze first the effects of financial constraints on the gains from acquisitions accrued to both targets and bidders. We investigate whether the degree of financial constraints on either bidders or targets has any impact on the value of the deal.

\subsection{Univariate Analysis}

Table 2 reports some descriptive characteristics at both company and deal level for targets (Panel A) and bidders (Panel B) respectively. All variables for both target and bidder companies are calculated from the most recent annual financial report prior to the acquisition announcement. Definitions of all variables are given in the Appendix. Constrained and unconstrained companies differ significantly from each other both at company and deal level irrespective of which classification of financial constraints we use. The only notable exception is when we use the payout ratio measure where the two groups of companies are less significantly different; this result is possibly due to the presence of a large number of non-dividend payers that substantially increases the overall number of firms in the sample. Also classifying companies based on the $\mathrm{KZ}$ measure results in groups of constrained and unconstrained companies which have different characteristics from those we obtain using other measures of financial constraints (similar to Almeida et al., 2004, among others).

Constrained companies (both in target and bidder groups) are on average smaller in terms of size and total sales and have higher debt costs and lower interest coverage ratios. Constrained firms have higher Tobin's Q compared to unconstrained firms, which may be due to their unexploited investment opportunities (Whited and $\mathrm{Wu}, 2006$ ). They also tend to hoard more cash to preserve their ability of funding investment options in the future without facing external capital market frictions (Almeida et al. 2004). Although property, plant and equipment constitutes a lower fraction of total assets in constrained companies, their level of investment (capital expenditure) with respect to their book value of assets is higher than unconstrained companies in the year preceding acquisitions. This may possibly be due to the fact that they are in an early stage of their business cycle and their level of investment compared to their assets in place is higher than that of unconstrained companies which may already have exploited most of their growth options. In line with previous studies, using the $\mathrm{KZ}$ measure results in groups of constrained and unconstrained companies which differ in their characteristics to the groups formed using other measures of financial constraints. For example, when using the $\mathrm{KZ}$ measure, constrained targets are larger in size compared to 
unconstrained targets, have lower Tobin's Q, hoard less cash and have higher ratios of plants, properties and equipment to total assets.

As for deal characteristics, constrained targets are less often involved in diversifying acquisitions, and less in hostile acquisitions, tender offers and competitive acquisitions. The ratio of stock payment to cash payment is higher in acquisitions of constrained firms than it is in acquisitions of unconstrained firms. On the other hand, unconstrained bidders seem to undertake more hostile acquisitions and tender offers, which might be attributable to agency problems, empire-building tendencies and managerial entrenchment, as the managers of such companies have more funds available for their acquisitions and are probably more determined to take their bids to conclusion. Finally, unconstrained bidders face more competition in their acquisitions and often settle a higher percentage of their acquisitions in cash. ${ }^{6}$ The differences between deal characteristics among constrained and unconstrained targets are not significant in most cases when the companies are categorized based on the $\mathrm{KZ}$ measure.

Please insert Table 2 here

Table 3 reports figures on premiums and abnormal returns for both targets and bidders. We classify the acquisitions on the basis of the target financial constraints first (Panel A) and then on the basis of the bidder financial constraints (Panel B), which helps us in a preliminarily investigation of the sources of the acquisitions' value.

Panel A shows that both target and bidder gains are significantly higher when targets are financially constrained than when targets are unconstrained, although the results are weaker for the HP index. For instance, when we use Composite I Index to classify financially constrained versus unconstrained targets, the premium for targets is $74.28 \%$, which is $16.11 \%$ higher than the premium received by unconstrained targets (57.17\%). Similarly, the abnormal return for bidders at the announcement date is positive when targets are financially constrained $(0.667 \%)$. On the contrary, it is significantly lower when targets are unconstrained (-2.104\%). These trends hold across different measures of financial constraints.

When we turn to Panel B, we notice that generally the degree of financial constraints of bidders does not appear to be associated with any value creation in the deal. For instance, using the Composite I Index, the difference in premiums between acquisitions with

\footnotetext{
${ }^{6}$ See Alshwer, Sibilkov, and Zaiats (2011) on methods of payment.
} 
constrained and acquisitions with unconstrained bidders is only $4.3 \%$ (with a p-value of 0.21 ). The only notable exception is the difference in target abnormal returns, which is statistically significant across all measures of financial constraints. ${ }^{7}$ Once again classifying bidders based on the $\mathrm{KZ}$ measure results in significant differences in gains to bidders and targets, which is contrary to the results we obtain under other measures of financial constraints. ${ }^{8}$

Overall these figures seem to suggest that the level of financial constraints of target companies is indeed an important source of the value created in US M\&A deals. In particular, when targets are financially constrained the acquisition seems to create a higher value for both parties. We find little evidence that bidder's financial constraints have any impact on value.

Please insert Table 3 here

\subsection{Multivariate Analysis}

We now examine the effect of financial constraints in target and bidder companies on premiums and abnormal returns using multivariate regressions. Clearly the advantage of the multivariate analysis is that it allows us to draw ceteris paribus conclusions, which simple ttests of means cannot do. Similar to Hubbard and Palia (1999), we estimate the following model:

$$
\text { Gains }_{i}=\alpha_{0}+\alpha_{1} T F C_{i}+\alpha_{2} T N F C_{i}+\alpha_{3} B F C_{i}+\alpha_{4} B N F C_{i}+\sum_{\mathrm{k}=1}^{\mathrm{n}} \beta_{k} X_{k, i}+\epsilon_{\mathrm{i}}
$$

where Gains $_{i}$ denotes the gains from acquisition $i$ accrued to target (either as \% Premium or $\mathrm{CAR}$ ) and to bidder (either as CAR or Dollar Value Abnormal Return) respectively; $T F C_{i}$ $\left(T N F C_{i}\right)$ is a binary variable equal to 1 if in acquisition $i$ the target company is classified as

\footnotetext{
${ }^{7}$ We have also calculated the total dollar abnormal return for each deal as the weighted average of dollar abnormal returns to targets and bidders (weighted by their market values prior to the deal). Interestingly, unreported figures show that the overall gain from acquiring a financially constrained target is on average $\$ 145$ million higher than the overall gain from acquiring an unconstrained target (in dollar value abnormal return), which is significant at $10 \%$ level. On the other hand, the level of financial constraints of bidder companies does not generate any significant difference in value across deals.

${ }^{8}$ An overall negative average abnormal returns to bidders acquiring public targets is a phenomenon documented in both US and international acquisitions (e.g., Fuller, Netter and Stegemoller, 2002; Faccio, McConnell, and Stolin, 2006)
} 
financially constrained (unconstrained); similarly, $B F C_{i}\left(B N F C_{i}\right)$ is a binary variable equal to 1 if in acquisition $i$ the bidder company is classified as finance

ally constrained (unconstrained); $X_{k, i}$ represents a vector of control variables at acquisition level (Diversifying Acquisitions, Hostile Acquisitions, Tender Offers, Competition, whether the deal was paid all in cash (All in cash) or all in stock (All in stock), and the relative size of the two firms (Relative size)). To minimize the risk of spurious inference we further include a proxy for the business cycle (Recession), Tobin's Q and free cash flow (of both bidder and target). ${ }^{9}$

The findings of our multivariate analysis are presented in Table 4. Panels A and B (C and D) show results for acquisition premiums and target percentage abnormal returns (bidder percentage abnormal returns and dollar value abnormal returns) respectively across the five measures of financial constraints. We also report the p-value of the difference between the coefficients that indicates the financial constraint status for targets and bidders separately.

Please insert Table 4 here

The regression results for acquisition premiums (Panel A) confirm that constrained targets attract significantly higher premiums compared to unconstrained targets. The p-value of the differences between target constraints dummies (TFC vs TNFC) further highlights the significant difference between premiums in acquisitions of constrained and unconstrained targets. For instance, other things being equal, a constrained target (based on Composite I Index) attracts $19.37 \%$ higher acquisition premium than an unconstrained target (difference between 9.585 and -9.786 ) with a p-value of less than 0.0001. This difference is significant across all measures of financial constraints. On the other hand, the level of financial constraint of acquirers does not significantly affect the acquisition premium in any of our models, apart from the one incorporating the $\mathrm{KZ}$ measure.

\footnotetext{
${ }^{9}$ Note that companies (both bidders and targets) in our sample are classified into three groups based on the tertile values of the financial constraints indices. The dummy variables in model (1) above represent two out of three categories, i.e. top (constrained) and bottom (unconstrained) tertiles. We therefore do not face the problem of perfect multicollinearity, more commonly known as the "dummy trap". Results are largely unaltered when we employ the financial constraints indices instead of the dummy variables to categorize targets or bidders based on their levels of constraints. Moreover, employing dummy variables facilitates comparison of our results with those of other papers in the literature, e.g. Hubbard and Palia (1999).
} 
Panel B presents results for our second proxy of target gains from acquisitions, target abnormal announcement returns. Across all models, apart from the last one using the HP index, p-values of the difference between the target constraints coefficients indicate that announcement returns for target companies with higher levels of financial constraint are significantly greater than for targets that are unconstrained. For instance, for our first classification of financial constraints, abnormal returns for constrained targets after the acquisition announcement are $9.02 \%$ higher than for unconstrained targets, with a p-value of less than 0.001. On the other hand, the difference between the bidder constraints coefficients is less pronounced and not significant in four out of five of our models.

Panel C and D report results for the gains for bidders. Overall, they show that the level of financial constraints of target companies is also relevant in determining the gains to the bidder (both in terms of percentage and dollar value abnormal returns). For instance, a bidder realizes $2.098 \%$ higher abnormal returns (difference between 2.219 and 0.121 ) when it bids for a constrained company (Composite I Index in Panel C) compared to when it bids for an unconstrained company, which is statistically significant at the 5\% level (p-value of 0.015). However, findings show that even the level of financial constraint of bidders seems somehow important when we consider their dollar value abnormal returns (Panel D). A possible interpretation of this evidence is that constrained bidders may be more selective in choosing a target to acquire. Under perfect capital markets, managers should invest in all projects with positive expected net present value. If projects were to be ranked based on their expected net present value per dollar of capital invested, managers should invest up to the point where, for the next project in line, the net present value is zero. Under financial constraints, however, it could be that managers would invest only in those projects with the highest expected net present value and leave on the table all the others. Although the company would be underinvesting, the investors in the market may still praise its investment choice. This could explain the positive reaction of the market at the announcement of the acquisition by a constrained bidder. Overall, results in Table 4 show that the level of financial constraint of target companies plays a major role in determining acquisition gains for both parties.

Estimates of the other control variables largely mirror findings in the literature. Diversifying Acquisitions generally has a negative and significant impact on the acquisition gains accruing to the target company (Gondhalekar, Sant and Ferris, 2004) rather than to the bidder (e.g. Morck, Shleifer, and Vishny, 1990; Amihud and Lev, 1981; Villalonga, 2004a, 2004b). Hostile Takeovers and Tender Offers seem to significantly benefit the target 
companies (as in Comment and Schwert, 1995; Schwert, 2000; Bange and Mazzeo, 2004), rather than the acquirers (Matsusaka, 1993; and Hubbard and Palia, 1999). ${ }^{10}$

In line with several other papers in the literature, we do not find any support for the theory that Competition among bidders results in higher premiums and target abnormal returns. On the contrary, our results are more in line with the findings of Boone and Mulherin (2007) and Gorbenko and Malenko (2013), among others, who show that the increase in the number of bidders does not necessarily have a positive impact on the acquisition premium and target gains. Indeed Gorbenko and Malenko (2013) show that targets with higher assetspecificity often have fewer competing bidders but experience larger premiums and abnormal returns, whereas bidders often face more competition in common value deals and these deals involve lower premiums and target returns. In line with this argument, financially constrained targets which are more likely to be classified as asset specific are subject to less competition and enjoy higher premiums and abnormal returns at the same time. As a robustness test, we create a direct measure of competition by counting the number of other bidders which bid for the same target in a +/-365 (and also 183) day window around the acquisition announcement. Interestingly, even if we use this direct measure of competition rather than the competition dummy used in our current regressions, the findings on the effect of competition on target and bidder gains are largely unaffected.

As for the methods of payment, we find that when acquisitions are paid in full either with cash or stock the effect is negative on the gains made by targets, but positive on bidders returns, in line with Huang and Walkling (1987) and Franks, Harris, and Titman (1991). During recession periods, when financial constraints are possibly more severe, acquisitions create value (in particular to target companies), complementing the evidence of Hovakimian (2011) on the benefits of internal capital markets in the presence of external capital market imperfections.

Acquisition premiums are inversely related to the target's Tobin's Q and positively related to the acquirer's $Q$, which suggests that targets that are undervalued are more likely to be acquired at higher premiums; while acquirers that are overvalued tend to pay higher premiums. We further find that the decrease in target free cash flows and the increase in acquirer free cash flows significantly increases acquisition premiums, which is in line with the findings of Lang, Stulz, and Walkling (1989, 1991).

\footnotetext{
${ }^{10}$ Lasfer and Morzaria (2004) show that both friendly and hostile deals outperform their sectors while 'lukewarm deals', i.e. those which lack vision and clarity of purpose, result in value destruction.
} 
We also show bidder returns to have a significant inverse relation with bidder's Tobin's Q. This is similar to the results in Dong, Hirshleifer, Richardson, and Teoh (2006), Moeller, Schlingemann and Stulz (2004) and Rhodes-Kropf, Robinson and Viswanathan (2005) who argue that since high Tobin's Q proxies for overvaluation, the market reacts negatively to acquisitions by the overvalued companies. ${ }^{11}$ Our results also show that bidder abnormal returns are inversely related to target's Tobin's Q, which is in line with evidence provided by Lang et al. (1991) and Servaes (1991). Further, we find the level of free cash flows in targets to have a positive (although marginal) effect and the bidder free cash flows to have a negative impact on bidder abnormal returns from acquisitions, consistent with Jensen's (1986) free cash flow argument.

\subsection{Propensity Score Matching}

As with most studies in corporate finance, our results may be well affected by an endogeneity problem. For instance, differences in characteristics of bidders may affect their choice of acquiring either constrained or unconstrained targets and at the same time their decision to offer a certain level of premium to one or the other type of targets. If this is the case, then our tests may be spurious as the results would be driven by bidder rather than target characteristics.

To address this issue, we use the propensity score matching procedure proposed by Rosenbaum and Rubin (1983). We identify a set of acquisitions of constrained target companies (treated group) that show no observable differences in bidder characteristics relative to a set of acquisitions of unconstrained target companies (control group). We also condition on the characteristics of the deal itself to further minimize the possibility of spurious matching. Thus, the two groups of deals are virtually indistinguishable from one another except for one key characteristic: the level of financial constraint of the target company. We then compare the acquisition premiums and the abnormal returns to both target and bidder companies between the two groups. As the acquisitions in the control group are restricted to a set of deals that are almost identical in terms of observable characteristics, acquisitions of constrained firms are expected to generate the same gains as acquisitions of unconstrained firms.

\footnotetext{
${ }^{11}$ Shleifer and Vishny (2003) suggest a model where bidders take advantage of their overvalued stock by locking in real assets, and Jensen (2005) explains how overvaluation might lead managers to make poor acquisitions and realize poor returns.
} 
We match observations based on a single scalar propensity score, which is the probability of being in the treated group (probability of being a constrained target) given the characteristics of the bidder and the deal itself. We estimate the propensity score using a set of covariates that includes: bidder's characteristics (level of financial constraint, Tobin's Q, free cash flow normalized by total assets and 2-digit US SIC industry), deal's characteristics (diversifying acquisition dummy, hostile takeover dummy, tender offer dummy, competition, method of payment, recessionary period, and relative size of bidder to target,), and the target 2-digit US SIC industry. ${ }^{12}$ We require that the maximum difference between the propensity score of the acquisitions of constrained firms and that of its matching peers does not exceed $0.5 \%$ in absolute value. Once we find the two groups of acquisitions, we compare the mean values of premium and abnormal returns of targets and bidders.

Table 5 shows the differences in mean of premiums and abnormal returns between the treated group (acquisitions of constrained targets) and control group (acquisitions of constrained targets). We repeat this analysis for each measure of financial constraints, as in previous tables.

Unreported p-values of the propensity scores (p-scores) are all above 0.8, which indicates that the two groups are virtually identical. More importantly, the differences in mean values of all variables of our interest (premium, abnormal returns to targets and to bidders) are positive and statistically significant across all columns (apart from bidder dollar abnormal returns for the payout ratio and the HP index, where the difference is marginally insignificant). For instance, the average premium of constrained targets is $74.47 \%$ as opposed to $54.37 \%$ of unconstrained targets, a difference that is statistically significant with a p-value of less than 0.001 (Composite I Index). This confirms our previous findings: even after controlling for bidder and deal characteristics, the observed gains from acquisitions are driven by the financial constraints of the acquired companies.

Please insert Table 5 here

To further corroborate this result, we repeat the analysis for the bidders' financial constraints. That is, we match acquisitions that involve constrained bidders (treated group)

\footnotetext{
${ }^{12}$ We use the routine provided by Leuven and Sianesi (2003) to match the observations based on propensity scores.
} 
with those involving unconstrained bidders (control group) based on the characteristics of the target, and the deal itself. ${ }^{13}$ Then, we compare the gains from acquisitions (premiums and abnormal returns for targets and bidders) across these two groups. Figures on the differences in mean are included in Table 6. Results suggest that once target and deal characteristics are properly controlled for, the financial constraints of bidders do not significantly affect neither the target nor the bidder gains. These findings are also very interesting, as they show that OLS regressions may tend to overstate the impact of bidder financial constraints on acquisitions gains.

Please insert Table 6 here

Overall, all results so far seem to point in the same direction. Financial constraints of target companies play an important role in generating acquisition value. In particular, constrained targets attract higher premiums (higher abnormal returns) as they appear to be more valuable to acquirers of all kinds, and benefit acquirers too. This complements evidence by Hubbard and Palia (1999) that shows that during the merger wave of the 1960s acquisitions have been value-enhancing for bidders only when the acquired companies were constrained. We provide direct evidence that more generally acquisitions of constrained targets are value-enhancing investments not only for bidders, but also (and more significantly) for the targets themselves.

This supports the idea that, to a potential bidder, financially constrained targets represent a pool of unexploited growth opportunities. Acquisition may alleviate their financial constraints, allowing them to have better access to either the external capital markets (as part of a larger organization) or the internal capital market created through the acquisition. This in turn would allow them to undertake profitable investments and so create value. This result corroborates very recent evidence by Erel et al. (2014): thanks to the availability of financial data on target firms both before and after the acquisition in the European market, they are able to show a significant decrease in the target's cash holdings, investment-cash flow sensitivities,

\footnotetext{
${ }^{13}$ As before, we estimate the propensity score using a set of covariates that includes: target characteristics (level of financial constraint, Tobin's Q, free cash flow normalized by total assets and 2-digit US SIC industry), deal characteristics (diversifying acquisition dummy, hostile takeover dummy, tender offer dummy, competition, method of payment, recessionary period, and relative size of bidder to target,), and the bidder 2-digit US SIC industry.
} 
and cash-cash flow sensitivities following an acquisition, coupled with a significant increase in investment. This would suggest that after the acquisition the target's financial constraints are eased and the company is more able to exploit its growth opportunities. ${ }^{14}$

\subsection{The Likelihood of Receiving an Acquisition Offer}

Previous findings show that financially constrained firms are expected to be more valuable acquisition targets because of their unexploited investment opportunities. We now investigate whether the degree of target financial constraint can be a reliable predictor of the probability of receiving acquisition bids.

To test this hypothesis, we examine the effect of financial constraints on the probability of being acquired in a similar setting, as in Palepu (1986) and Comment and Schwert (1995). We estimate the following acquisition likelihood model:

$$
p(i, t)=\frac{1}{\left\{1+\exp \left[-\left(\gamma_{1} \text { Financial Constraints }_{(i, t)}+\sum_{\mathrm{k}=2}^{\mathrm{n}} \gamma_{\mathrm{k}} \mathrm{X}_{\mathrm{k},(\mathrm{i}, \mathrm{t})}\right)\right]\right\}}
$$

where $p(i, t)$ is the probability that the company $i$ will be acquired at time $t$; Financial Constraints $_{(i, t)}$ is a proxy of the level of financial constraints of company $i$ at time $t$ (it is alternatively proxied by Composite I Index, Composite II Index and Payout Ratio); $\mathrm{X}_{\mathrm{k},(\mathrm{i}, \mathrm{t})}$ denotes a vector of control variables that includes: Average Excess Return, GrowthResource Imbalance, Average Sales Growth, Average Liquid Assets, Average PPE/TA and Average Leverage, Industry Dummy, Size, Market to Book, and Price to Earnings. All independent variables are winsorized at $1 \%$.

Table 7 reports mean and median values of all variables included in model (2) across the group of (actual) target companies and all the others. According to our figures, target companies appear to be significantly more constrained than non-targets and have lower Market to Book ratio. The significant difference in Industry Dummy between the two groups suggests that the incidence of an acquisition in a specific industry increases the chances of

\footnotetext{
${ }^{14}$ For US companies, financial data on target firms both before and after the acquisition are generally not publicly available. However, in an untabulated test we measured the level of financial constraint for each deal before and after the acquisition. In particular, we calculated the size-weighted average of the bidder and target Composite I index in the second and third year before the acquisition. We then compared this weighted average with the level of financial constraint (Composite I index) of the "new merged" company in the second and third year after the acquisition. Untabulated results show that, after controlling for bidder and deal characteristics, the decrease in the overall financial constraints is significantly more pronounced when the target company was financially constrained before the acquisition as opposed to the decrease of overall financial constraints when the target company was unconstrained before the acquisition.
} 
takeover bids for other companies in that industry in the future. Target companies also appear to be less liquid and smaller in size, have higher leverage ratios and lower price to earnings ratios. However, there seems to be no significant difference between the two groups in terms of other firm characteristics.

Please insert Table 7 here

The logit regression results are presented in Table 8. In column (1) we include a baseline model similar to those proposed by previous studies (e.g. Ambrose and Megginson, 1992; Song and Walking, 1993; Comment and Schwert, 1995; Billett and Xue, 2007). We then augment the baseline model with one of the financial constraints variables. ${ }^{15}$

All proxies of financial constraints have a significant and positive impact on the acquisition likelihood. In other words, higher degrees of financial constraint in companies are associated with significantly higher probability of receiving takeover offers. More importantly, financial constraints are not only statistically significant, but also economically important. The marginal effects of financial constraints proxies are among the highest marginal effects on the acquisition likelihood. A 1\% increase in the level of financial constraint (Composite I Index) increases the likelihood of becoming a target by $0.202 \%$. This result is quite remarkable: the effect of financial constraint is the largest of all variables included in the model. For instance, this effect is considerably larger than firm size, which has a marginal effect of $-0.082 \%$ on the acquisition likelihood. More generally, the average effect of all other control variables is about $0.12 \%$. The marginal effect of financial constraints is also economically important when compared to the baseline probability of $5.24 \%$. On average, a $1 \%$ increase in the level of financial constraints increases the chance of being subject to a takeover attempt by $3.85 \%$. This further illustrates the major impact of constraints on the likelihood of a company becoming an acquisition target.

The remaining control variables show estimated coefficients similar to previous studies. The Average Excess Returns does not seem to be relevant for the acquisition likelihood, as shown in Ambrose and Megginson (1992) and Comment and Schwert (1995). In line with

\footnotetext{
${ }^{15}$ As a robustness test, we include financial constraints dummies rather than the indices. Untabulated results are qualitatively similar to those presented here.
} 
Palepu (1986), we find the mismatch between the firm's growth and resources to have a positive impact on acquisition likelihood, although it loses its significance when we include our two composite measures of financial constraints in the models. Similar to Palepu (1986) and Ambrose and Megginson (1992), we find the Average Liquid Assets of the firm to have a negative effect on the acquisition likelihood, although here the effect is more significant. We also find a more significant impact of tangible assets, as opposed to the results of Billett and Xue (2007). Our finding on the effect of Leverage on acquisition likelihood is somewhat different from other papers, as we find this effect to be significantly positive whereas the impact is found to be negative or insignificant in some other studies. The positive and significant estimate of Industry dummy is in line with the idea of "industry 'acquisition waves' that last for more than one year" (Gort, 1969; Palepu, 1986). In line with the literature in general, we find firm size to have a negative and significant impact on the firm's acquisition likelihood. Our findings on the significant negative association between the company's market to book ratio and its acquisition likelihood, as well as the insignificant effect of the price to earnings ratio on takeover probability, are also in line with most studies.

Overall, these results suggest that the degree of financial constraint is among the most important predictors of acquisition likelihood. This effect remains qualitatively unchanged with changes in model specification, variable definition and measure of financial constraints. Further, focusing on only completed acquisitions does not alter the results significantly. The high marginal effect of the changes in financial constraint variables in the logit models amid inclusion of size and other control variables further highlights the importance of the effect of degrees of financial constraint on acquisition likelihoods.

Please insert Table 8 here

\section{Conclusions}

As the economy recovers from the recent financial crisis, a new wave of mergers and acquisitions (M\&A) is starting to rise. At the same time, many companies are still affected by the consequences of the crisis, and the effect of their financial constraints on M\&A attracts increasing attention from academics. 
In this study, using a large sample of US acquisitions data from the period 1985 to 2013, we examine the effect of financial constraints of bidder and target companies on (1) gains from acquisitions and (2) the probability of being taken over. We use a variety of financial constraints measures to identify financially constrained and unconstrained companies.

We find that both targets and bidders significantly gain more when financially constrained companies are acquired. We show that acquisition premiums and target abnormal returns are significantly higher when targets are financially constrained. We further show that acquisitions of financially constrained targets are generally more profitable for bidders too, as these companies have more unexploited investment opportunities and more scope for future growth. On the other hand, we fail to find any significant impact of the degree of financial constraints in bidder companies.

We then show that stronger financial constraint in a company has a positive and significant impact on its acquisition likelihood. The marginal effect of changes in the degree of financial constraint on acquisition likelihood is considerably higher than it is for most of the other predictors commonly used in the finance literature.

Our findings shed new light on the effect of financial constraints on gains and value creation in acquisitions as well as on acquisition likelihood, and contribute to both M\&A and financial constraints literatures. These results are especially interesting as they gauge the effect of financial constraints on value creation within M\&As. 


\section{References}

Almeida, H., M. Campello, and D. Hackbarth, 2011, "Liquidity Mergers," Journal of Financial Economics, 102, 526-558

Almeida, H., M. Campello, and M. Weisbach, 2004, "The cash flow sensitivity of cash," Journal of Finance, 59, 1777-1804.

Alshwer, A., V. Sibilkov, and N.Zaiats, 2011, "Financial constraints and the method of payments in mergers and acquisitions," Working Paper, Sheldon B. Lubar School of Business, University of Wisconsin.

Ambrose, B., and W. Megginson, 1992, "The role of asset structure, ownership structure, and takeover defences in determining acquisition likelihood," Journal of Financial and Quantitative Analysis, 27, 575-589.

Amihud, Y., and B. Lev, 1981, "Risk reduction as a managerial motive for conglomerate mergers," Rand Journal of Economics, 12, 605-618.

Bange, M. M., and M. A. Mazzeo, 2004, "Board composition, board effectiveness, and the observed form of takeover bids," The Review of Financial Studies, 17(4), 1185-1215.

Billett, M.T., and Xue, H., 2007, “The Takeover Deterrent Effect Of Open Market Share Repurchases," The Journal of Finance, 62, 1827-1850.

Boone, A. L. and J. H. Mulherin, 2007: How are firms sold? Journal of Finance, 62, 847-875.

Campello, M., and L. Chen, 2010, “Are financial constraints priced? Evidence from firm fundamentals and stock returns," Journal of Money, Credit and Banking, 1185-1198.

Comment, R., and W. Schwert, 1995, "Poison or placebo? Evidence on the deterrence and wealth effects of modern antitakeover measures," Journal of Financial Economics, 39(1), 3-43.

Dong, M., D. Hirshleifer, S. Richardson, and S. Teoh, 2006, "Does investor misvaluation drive the takeover market?," Journal of Finance, 61, 725-762.

Erel, I., Y. Jang, and M. Weisbach, 2014, “Do Acquisitions Relieve Target Firms' Financial Constraints?" Journal of Finance, forthcoming.

Faccio, M., J.J. McConnell, and D. Stolin, 2006, "Returns to acquirers of listed and unlisted targets," Journal of Financial and Quantitative Analysis, 41, 197-220.

Fazzari, S., R. G. Hubbard, and B. C. Petersen, 1988, "Financing constraints and corporate investment," Brookings Papers on Economic Activity, 1, 141-195.

Fee, C.E., C.J. Hadlock, and S. Thomas, 2006, "Corporate equity ownership and the governance of product market relationships,” Journal of Finance, 61, 1217-1251. 
Franks, J. R., R. S. Harris, and S. Titman, 1991, “The postmerger share-price performance of acquiring firms," Journal of Financial Economics, 29, 81-96.

Fuller, K., J. Netter, and M. Stegemoller, 2002, "What do returns to acquiring firms tell us? Evidence from firms that make many acquisitions," Journal of Finance, 57, 1763-1793.

Gorbenko, A. S. and A. Malenko, 2013: A theory of initiation of takeover contests. Working Paper, EFA Meeting.

Gondhalekar, V. B., R. R. Sant, and S. P. Ferris, 2004, "The price of corporate acquisition: determinants of takeover premia," Applied Economics Letters, 11(12), 735-739.

Gort, M., 1969, "An economic disturbance theory of mergers," Quarterly Journal of Economics, 3, 624-642.

Guariglia, A., 2008, "Internal financial constraints, external financial constraints, and investment choice: Evidence from a panel of UK firms," Journal of Banking \& Finance $32,1795-1809$.

Hadlock, C., and J. Pierce, 2010, "New evidence on measuring financial constraints: moving beyond the KZ index," Review of Financial Studies, 23(5), 1909-1940.

Hovakimian, G., 2011, "Financial constraints and investment efficiency: Internal capital allocation across the business cycle,” Journal of Financial Intermediation, 20(2), 264283.

Huang, Y. S., and R. A. Walkling, 1987, “Target abnormal returns associated with acquisition announcements: payment, acquisition form, and managerial resistance," Journal of Financial Economics, 19, 329-49.

Hubbard, R. G., and D. Palia, 1999, "A reexamination of the conglomerate merger wave in the 1960s: an internal capital markets view," Journal of Finance, 54, 1131-1152.

Jagannathan, M., C.P. Stephens, and M.S. Weisbach, 2000, "Financial flexibility and the choice between dividends and stock repurchases," Journal of Financial Economics 57, $355-384$.

Jensen, M. C., 1986, "Agency costs of free cash flow, corporate finance, and takeovers," American Economic Review, 76, 323-329.

Jensen, M., 2005, “Agency Costs of Overvalued Equity,” Financial Management, 34, 5-19.

Lasfer, M., and K. Morzaria, 2004, 'Bidder's Attitude Determines M\&a Success', International Financial Law Review, April, Supplement, pp.187-189.

Lamont, O., C. Polk, and J. Saá-Requejo, 2001, "Financial Constraints and Stock Returns," Review of Financial Studies, 14, 529-554 
Lang, L. H. P., R. M. Stulz, and R. A. Walkling, 1989, “Managerial performance, Tobin's Q, and the gains from successful tender offers," Journal of Financial Economics, 24, 137154.

Lang, L. H. P., R. M. Stulz, and R. A. Walkling, 1991, "A test of the free cash flow hypothesis: the case of bidder returns," Journal of Financial Economics, 29, 315-336.

Leuven, E. and B. Sianesi, 2003, "PSMATCH2: Stata module to perform full Mahalanobis and propensity score matching, common support graphing, and covariate imbalance testing”. http://ideas.repec.org/c/boc/bocode/s432001.html. Version 4.0.4

Liao, R. C., 2014, "What drives corporate block acquisitions? The case for financial constraints," Journal of Corporate Finance 26, 78-95.

Malatesta, P. H., 1983, “The wealth effect of merger activity and the objective functions of merged firms," Journal of Financial Economics 11, 155-181.

Matsusaka, J. G., 1993, “Takeover motives during the conglomerate merger wave,” RAND Journal of Economics, 24, 357-379.

Moeller, S. B., F. P. Schlingemann, and R. M. Stulz, 2004, "Firm size and the gains from acquisitions," Journal of Financial Economics, 73, 201-228.

Morck, R., A. Shleifer, and R.W. Vishny, 1990, "Do managerial objectives drive bad acquisitions?," Journal of Finance, 45, 31-48.

Officer, M., 2003, "Termination fees in mergers and acquisitions," Journal of Financial Economics, 69, 431-467.

Ouimet, P.P., 2013, "What motivates minority acquisitions? The trade-offs between a partial equity stake and complete integration”, Review of Financial Studies, 26, 1021-1047

Palepu, K. G., 1986, "Predicting takeover targets: A methodological and empirical analysis," Journal of Accounting and Economics, 8, 3-35.

Rhodes-Kropf, M., D. Robinson, and S. Viswanathan, 2005, "Valuation waves and merger activity: The empirical evidence," Journal of Financial Economics, 77, 561-603.

Rosenbaum, P., and F. B. Rubin, 1983, "The Central Role of the Propensity Score in Observational Studies for Causal Effects," Biometrika, 70. 41-55.

Schiantarelli, F., 1995, "Financial constraints and investment: Methodological issues and international evidence," Oxford Review of Economic Policy 12, 70-89.

Schwert, G. W., 1996, "Markup pricing in mergers and acquisitions," Journal of Financial Economics, 41(2),153-192. 
Schwert, G.W., 2000, "Hostility in takeovers: in the Eyes of the Beholders?" Journal of Finance 55, 2599-2640.

Servaes, H., 1991, “Tobin's Q, agency costs, and corporate control: An empirical analysis of firm specific parameters," Journal of Finance 46, 409-419.

Shleifer, A., and R. W. Vishny, 2003, "Stock market driven acquisitions," Journal of Financial Economics, 70, 295-312.

Song, M.H., and Walkling, R.A., 1993, “The Impact of Managerial Ownership on Acquisition Attempts and Target Shareholder Wealth", Journal of Financial and Quantitative Analysis 28, 439-457.

Villalonga, B., 2004a, "Diversification discount or premium? New evidence from the business information tracking series,” Journal of Finance, 59, 479-506.

Villalonga, B., 2004b, "Does diversification cause the "diversification discount?" Financial Management, 33, 5-27.

Whited, T. M., and G. Wu, 2006, "Financial constraints risk," Review of Financial Studies, 19, 531-559. 


\section{Table 1. Sample Distribution by Level of Financial Constraints}

This table reports the number of acquisition deals in our sample based on the level of financial constraints of target and bidder companies. Our sample contains all U.S. acquisitions between 1985 and 2013 listed on SDC where both bidder and target companies are publicly traded with accounting and share price information available in COMPUSTAT and CRSP. We exclude bidders and targets from the financial and regulated utilities industries. We require transaction values to be larger than $\$ 1 \mathrm{~m}$ and $1 \%$ of the bidder's market value. We also exclude targets that are defined as "in bankrupt" in SDC. $T F C$ denotes "financially constrained target"; $T N F C$ denotes "unconstrained target"; \%TFC denotes the percentage of deals with financially constrained targets according to each measure of financial constraints; $B F C$ denotes "financially constrained bidder; $B N F C$ denotes "unconstrained bidder"; $\% B F C$ denotes the percentage of deals with financially constrained bidders according to each measure of financial constraints. Measures of financial constraints are described in detail in the Appendix.

\begin{tabular}{|c|c|c|c|c|c|c|}
\hline No. of Acquisition deals & TFC & TNFC & $\% \mathrm{TFC}$ & BFC & BNFC & $\%$ BFC \\
\hline Composite I Index & 592 & 937 & 21.85 & 249 & 1,731 & 8.64 \\
\hline Composite II Index & 703 & 978 & 28.47 & 401 & 1,719 & 14.70 \\
\hline Payout Ratio & 1,421 & 767 & 52.63 & 1046 & 1122 & 38.53 \\
\hline $\mathrm{KZ}$ & 748 & 930 & 26.45 & 501 & 1070 & 18.50 \\
\hline $\mathrm{HP}$ & 343 & 1100 & 11.18 & 162 & 1823 & 5.38 \\
\hline
\end{tabular}




\section{Table 2. Summary Statistics}

This table presents some descriptive characteristics at both company and deal level, based on the level of financial constraints, of target (Panel A) and bidder (Panel B) companies respectively. All variables for both targets and bidders are calculated from the last annual financial report available prior to acquisition announcement. $T F C$ denotes "financially constrained target"; $T N F C$ denotes "unconstrained target"; $B F C$ denotes "financially constrained bidder"; $B N F C$ denotes "unconstrained bidder". Measures of financial constraints and definitions of all other variables are described in detail in the Appendix. This table also reports the p-values for the ttests of equality in the means of each variable between the two sub-groups.

Panel A. Targets

\begin{tabular}{|c|c|c|c|c|c|c|c|c|c|c|c|c|c|c|c|}
\hline & \multicolumn{3}{|c|}{ Composite I Index } & \multicolumn{3}{|c|}{ Composite II Index } & \multicolumn{3}{|c|}{ Payout Ratio } & \multicolumn{3}{|c|}{ KZ } & \multicolumn{3}{|c|}{ HP } \\
\hline & TFC & TNFC & $\begin{array}{c}\mathrm{P}- \\
\text { value }\end{array}$ & TFC & TNFC & $\begin{array}{c}\text { P- } \\
\text { value }\end{array}$ & TFC & TNFC & $\begin{array}{c}\mathrm{P}_{-} \\
\text {value }\end{array}$ & TFC & TNFC & $\begin{array}{c}\mathrm{P}- \\
\text { value }\end{array}$ & TFC & TNFC & $\begin{array}{c}\text { P- } \\
\text { value }\end{array}$ \\
\hline \multicolumn{16}{|l|}{ Company level } \\
\hline Total Assets $(\$ \mathrm{~m})$ & 123 & 2,126 & 0.000 & 218 & 2,033 & 0.000 & 443 & 1,562 & 0.000 & 508 & 865 & 0.001 & 14.328 & 1,901 & 0.000 \\
\hline Sales $(\$ \mathrm{~m})$ & 132 & 1,988 & 0.000 & 186 & 1,925 & 0.000 & 430 & 1,465 & 0.000 & 447 & 698 & 0.003 & 18.53 & 1,803 & 0.000 \\
\hline Cost of Debt (\%) & 0.109 & 0.099 & 0.186 & 0.112 & 0.096 & 0.012 & 0.107 & 0.105 & 0.778 & 0.128 & 0.101 & 0.039 & 0.137 & 0.091 & 0.001 \\
\hline Coverage Ratio & -30.414 & 49.043 & 0.000 & -24.648 & 23.157 & 0.000 & 8.527 & 22.449 & 0.005 & 40.467 & -7.073 & 0.000 & -26.991 & 20.639 & 0.000 \\
\hline Total Debt/BVE (\%) & 0.379 & 0.320 & 0.000 & 0.376 & 0.393 & 0.219 & 0.313 & 0.324 & 0.359 & 0.128 & 0.563 & 0.000 & 0.209 & 0.406 & 0.000 \\
\hline Tobin's Q & 2.248 & 1.865 & 0.008 & 2.075 & 1.594 & 0.000 & 1.948 & 2.146 & 0.116 & 2.784 & 1.781 & 0.000 & 2.779 & 1.638 & 0.000 \\
\hline Cash Holding/PPE & 3.391 & 2.938 & 0.356 & 4.95 & 1.189 & 0.000 & 4.511 & 4.515 & 0.994 & 13.078 & 0.742 & 0.000 & 7.768 & 1.705 & 0.000 \\
\hline CapEx/TA (\%) & 0.089 & 0.086 & 0.694 & 0.102 & 0.087 & 0.037 & 0.091 & 0.095 & 0.459 & 0.088 & 0.103 & 0.023 & 0.091 & 0.081 & 0.282 \\
\hline PPE/TA (\%) & 0.263 & 0.290 & 0.022 & 0.254 & 0.341 & 0.000 & 0.262 & 0.294 & 0.001 & 0.122 & 0.404 & 0.000 & 0.201 & 0.330 & 0.000 \\
\hline No. of firms & 559 & 849 & & 662 & 878 & & 1,329 & 711 & & 693 & 881 & & 328 & 998 & \\
\hline \multicolumn{16}{|l|}{ Deal level } \\
\hline Trans. Value (\$m) & 283 & 3,595 & 0.000 & 425 & 3,327 & 0.000 & 674 & 3,062 & 0.000 & 1,355 & 1,020 & 0.076 & 97.585 & 3,296 & 0.000 \\
\hline Diversifying (\%) & 0.324 & 0.380 & 0.026 & 0.343 & 0.397 & 0.024 & 0.354 & 0.369 & 0.487 & 0.376 & 0.320 & 0.015 & 0.391 & 0.376 & 0.635 \\
\hline Hostile $(\%)$ & 0.044 & 0.125 & 0.000 & 0.054 & 0.131 & 0.000 & 0.075 & 0.117 & 0.002 & 0.058 & 0.076 & 0.143 & 0.015 & 0.125 & 0.000 \\
\hline Tender Offer $(\%)$ & 0.066 & 0.163 & 0.000 & 0.077 & 0.174 & 0.000 & 0.096 & 0.142 & 0.002 & 0.095 & 0.119 & 0.110 & 0.035 & 0.164 & 0.000 \\
\hline Competition (\%) & 0.176 & 0.266 & 0.000 & 0.183 & 0.272 & 0.000 & 0.204 & 0.259 & 0.004 & 0.212 & 0.198 & 0.481 & 0.090 & 0.284 & 0.000 \\
\hline Of Cash $(\%)$ & 37.981 & 51.887 & 0.000 & 39.919 & 52.856 & 0.000 & 42.084 & 50.969 & 0.000 & 41.536 & 42.027 & 0.834 & 26.728 & 52.79 & 0.000 \\
\hline Of Stock (\%) & 63.025 & 51.724 & 0.000 & 60.634 & 50.968 & 0.000 & 59.174 & 51.03 & 0.000 & 60.002 & 58.439 & 0.491 & 73.548 & 50.347 & 0.000 \\
\hline No. of deals & 592 & 937 & & 703 & 978 & & 1,421 & 767 & & 748 & 930 & & 343 & 1,100 & \\
\hline
\end{tabular}


Table 2. Summary Statistics (Continued)

Panel B. Bidders

\begin{tabular}{|c|c|c|c|c|c|c|c|c|c|c|c|c|c|c|c|}
\hline & \multicolumn{3}{|c|}{ Composite I Index } & \multicolumn{3}{|c|}{ Composite II Index } & \multicolumn{3}{|c|}{ Payout Ratio } & \multicolumn{3}{|c|}{$\mathbf{K Z}$} & \multicolumn{3}{|c|}{ HP } \\
\hline & $\mathrm{BFC}$ & BNFC & $\begin{array}{c}\mathrm{P}- \\
\text { value }\end{array}$ & $\mathrm{BFC}$ & BNFC & $\begin{array}{c}\mathrm{P}- \\
\text { value }\end{array}$ & $\mathrm{BFC}$ & BNFC & $\begin{array}{c}\mathrm{P}- \\
\text { value }\end{array}$ & $\mathrm{BFC}$ & $\mathrm{BNFC}$ & $\begin{array}{c}\mathrm{P}- \\
\text { value }\end{array}$ & $\mathrm{BFC}$ & BNFC & $\begin{array}{c}\mathrm{P}- \\
\text { value }\end{array}$ \\
\hline \multicolumn{16}{|l|}{ Company Level } \\
\hline Total Assets (\$m) & 158 & 6,198 & 0.000 & 424 & 6,187 & 0.000 & 1,721 & 6,700 & 0.000 & 1,981 & 3,628 & 0.000 & 15 & 4,756 & 0.000 \\
\hline Sales $(\$ \mathrm{~m})$ & 110 & 5,046 & 0.000 & 307 & 5,064 & 0.000 & 1,435 & 5,342 & 0.000 & 1,487 & 2,874 & 0.000 & 13 & 4,173 & 0.000 \\
\hline Cost of Debt (\%) & 0.113 & 0.08 & 0.000 & 0.109 & 0.080 & 0.000 & 0.095 & 0.081 & 0.000 & 0.095 & 0.095 & 0.945 & 0.12 & 0.083 & 0.000 \\
\hline Coverage Ratio & -39.818 & 40.202 & 0.000 & -26.078 & 26.758 & 0.000 & 22.344 & 29.316 & 0.123 & -3.643 & 39.578 & 0.000 & -22.352 & 27.814 & 0.000 \\
\hline Total Debt/BVE (\%) & 0.357 & 0.329 & 0.173 & 0.352 & 0.365 & 0.433 & 0.314 & 0.333 & 0.090 & 0.566 & 0.193 & 0.000 & 0.242 & 0.349 & 0.000 \\
\hline Tobin's Q & 3.397 & 2.215 & 0.000 & 3.088 & 2.016 & 0.000 & 2.641 & 2.253 & 0.002 & 2.154 & 3.301 & 0.000 & 4.269 & 2.178 & 0.000 \\
\hline Cash Holding/PPE & 6.256 & 2.234 & 0.000 & 8.119 & 1.428 & 0.000 & 5.204 & 2.970 & 0.000 & 0.836 & 9.667 & 0.000 & 12.814 & 1.899 & 0.000 \\
\hline CapEx/TA $(\%)$ & 0.143 & 0.085 & 0.000 & 0.155 & 0.088 & 0.000 & 0.115 & 0.082 & 0.000 & 0.147 & 0.089 & 0.000 & 0.146 & 0.085 & 0.001 \\
\hline PPE/TA $(\%)$ & 0.259 & 0.284 & 0.122 & 0.240 & 0.307 & 0.000 & 0.262 & 0.275 & 0.169 & 0.448 & 0.149 & 0.000 & 0.225 & 0.297 & 0.000 \\
\hline No. of Observations & 227 & 961 & & 344 & 941 & & 796 & 702 & & 371 & 709 & & 156 & 986 & \\
\hline \multicolumn{16}{|l|}{ Deal Level } \\
\hline Trans. Value (\$m) & 213 & 2,217 & 0.000 & 356 & 2,166 & 0.000 & 792 & 2,195 & 0.000 & 889 & 1,434 & 0.01 & 65 & 2,053 & 0.000 \\
\hline Diversifying (\%) & 0.353 & 0.385 & 0.336 & 0.372 & 0.390 & 0.499 & 0.364 & 0.396 & 0.131 & 0.279 & 0.379 & 0.000 & 0.469 & 0.397 & 0.080 \\
\hline Hostile (\%) & 0.028 & 0.079 & 0.000 & 0.052 & 0.084 & 0.016 & 0.077 & 0.084 & 0.588 & 0.092 & 0.074 & 0.237 & 0.031 & 0.085 & 0.000 \\
\hline Tender Offer (\%) & 0.060 & 0.113 & 0.002 & 0.062 & 0.116 & 0.000 & 0.098 & 0.119 & 0.133 & 0.124 & 0.090 & 0.047 & 0.062 & 0.122 & 0.004 \\
\hline Competition (\%) & 0.084 & 0.285 & 0.000 & 0.125 & 0.286 & 0.000 & 0.175 & 0.287 & 0.000 & 0.148 & 0.242 & 0.000 & 0.025 & 0.287 & 0.000 \\
\hline Of Cash (\%) & 16.058 & 55.957 & 0.000 & 23.524 & 56.214 & 0.000 & 35.796 & 57.325 & 0.000 & 39.375 & 42.604 & 0.206 & 17.223 & 54.425 & 0.000 \\
\hline Of Stock $(\%)$ & 83.327 & 46.754 & 0.000 & 76.040 & 46.580 & 0.000 & 65.020 & 44.573 & 0.000 & 61.343 & 59.303 & 0.399 & 82.095 & 48.479 & 0.000 \\
\hline No. of Observations & 249 & 1731 & & 401 & 1719 & & 1046 & 1122 & & 501 & 1070 & & 162 & 1823 & \\
\hline
\end{tabular}




\section{Table 3. Gains from Acquisitions Based on Levels of Financial Constraints}

This table presents mean values of target and bidder gains from acquisitions based on the level of financial constraints of targets (Panel A) and bidders (Panel B). $T F C$ denotes "financially constrained target"; $T N F C$ denotes "unconstrained target"; $B F C$ denotes "financially constrained bidder"; $B N F C$ denotes "unconstrained bidder". Measures of financial constraints and definitions of all other variables are described in detail in the Appendix. This table also reports the p-values for the ttests of equality in mean of each variable between the two sub-groups.

Panel A. Targets' Financial Constraints

\begin{tabular}{|c|c|c|c|c|c|c|c|c|}
\hline & \multicolumn{4}{|c|}{ Composite I Index } & \multicolumn{4}{|c|}{ Composite II Index } \\
\hline & TFC & TNFC & Diff. & P-val & TFC & TNFC & Diff. & P-val \\
\hline Premium $(\%)$ & 74.281 & 58.169 & 16.112 & 0.000 & 71.834 & 61.509 & 10.325 & 0.000 \\
\hline Target 11-day CAR (\%) & 25.642 & 20.554 & 5.089 & 0.001 & 24.529 & 20.215 & 4.314 & 0.002 \\
\hline Bidder 11-day CAR (\%) & 0.667 & -2.104 & 2.771 & 0.000 & -0.181 & -1.745 & 1.563 & 0.009 \\
\hline Bidder AR (\$mil) & 5.749 & -310.109 & 315.858 & 0.001 & 1.079 & -238.349 & 239.429 & 0.000 \\
\hline
\end{tabular}

\begin{tabular}{|c|c|c|c|c|c|c|c|c|c|c|c|c|}
\hline & \multicolumn{4}{|c|}{ Payout Ratio } & \multicolumn{4}{|c|}{$\mathbf{K Z}$} & \multicolumn{4}{|c|}{ HP } \\
\hline & TFC & TNFC & Diff. & P-val & TFC & TNFC & Diff. & P-val & TFC & TNFC & Diff. & P-val \\
\hline Premium (\%) & 67.392 & 58.991 & 8.401 & 0.000 & 73.037 & 60.206 & 12.831 & 0.000 & 67.409 & 62.727 & 4.682 & 0.151 \\
\hline Target 11-day CAR (\%) & 23.760 & 20.578 & 3.182 & 0.016 & 20.660 & 22.009 & -1.349 & 0.343 & 21.178 & 20.415 & 0.763 & 0.646 \\
\hline Bidder 11-day CAR (\%) & -0.871 & -1.706 & 0.835 & 0.127 & 0.063 & -3.018 & 3.082 & 0.000 & 1.030 & -1.929 & 2.960 & 0.000 \\
\hline Bidder AR (\$mil) & 5.649 & -197.174 & 202.823 & 0.003 & -15.705 & -84.628 & 68.923 & 0.316 & -89.842 & -216.280 & 126.438 & 0.209 \\
\hline
\end{tabular}


Table 3. Gains from Acquisitions Based on Levels of Financial Constraints (Continued)

Panel B. Bidders' Financial Constraints

\begin{tabular}{|c|c|c|c|c|c|c|c|c|}
\hline & \multicolumn{4}{|c|}{ Composite I Index } & \multicolumn{4}{|c|}{ Composite II Index } \\
\hline & $\mathrm{BFC}$ & BNFC & Diff. & P-val & $\mathrm{BFC}$ & BNFC & Diff. & P-val \\
\hline Premium $(\%)$ & 68.626 & 64.294 & 4.332 & 0.209 & 66.136 & 64.518 & 1.618 & 0.55 \\
\hline Target 11-day CAR (\%) & 19.230 & 24.977 & -5.747 & 0.002 & 18.166 & 24.555 & -6.389 & 0.000 \\
\hline Bidder 11-day CAR (\%) & -1.400 & -1.638 & 0.237 & 0.759 & -0.872 & -1.299 & 0.428 & 0.502 \\
\hline Bidder AR (\$mil) & -27.755 & -164.995 & 137.241 & 0.132 & -43.043 & -158.437 & 115.394 & 0.103 \\
\hline
\end{tabular}

\begin{tabular}{|c|c|c|c|c|c|c|c|c|c|c|c|c|}
\hline & \multicolumn{4}{|c|}{ Payout Ratio } & \multicolumn{4}{|c|}{$\mathbf{K Z}$} & \multicolumn{4}{|c|}{ HP } \\
\hline & $\mathrm{BFC}$ & BNFC & Diff. & P-val & $\mathrm{BFC}$ & BNFC & Diff. & P-val & $\mathrm{BFC}$ & BNFC & Diff. & $\mathrm{P}$-val \\
\hline Premium (\%) & 64.007 & 63.189 & -0.818 & 0.695 & 71.320 & 62.369 & 8.951 & 0.001 & 65.226 & 65.080 & 0.146 & 0.973 \\
\hline Target 11-day CAR (\%) & 19.081 & 25.012 & -5.931 & 0.000 & 19.804 & 23.795 & -3.991 & 0.014 & 20.728 & 24.571 & -3.842 & 0.093 \\
\hline Bidder 11-day CAR (\%) & -1.186 & -1.638 & 0.452 & 0.390 & 0.405 & -2.377 & 2.783 & 0.000 & 0.665 & -1.405 & 2.070 & 0.015 \\
\hline Bidder AR (\$mil) & -65.127 & -237.968 & 172.841 & 0.010 & -19.991 & -148.299 & 128.308 & 0.055 & -8.763 & -155.823 & 147.060 & 0.267 \\
\hline
\end{tabular}


Table 4. Financial Constraints and Premiums and Announcement Returns: OLS analysis

This table reports OLS results of model (1) where Gains $i$ denotes the gains from acquisition $i$ accrued to target as Premium (Panel A) or 11-day CAR (Panel B), and to bidder as 11-day CAR (Panel C) or Dollar Value Abnormal Return (Panel D). TFC (BFC) is a dummy variable which takes the value of 1 if the target (bidder) is categorized as financially constrained and 0 otherwise; TNFC (BNFC) is a dummy variable which takes the value of 1 if the target (bidder) is categorized as unconstrained and 0 otherwise. Measures of financial constraints and definitions of all other variables are described in detail in the Appendix. P-values, adjusted for heteroskedasticity, are reported in brackets below the coefficients. Differences in the coefficients of the two dummies of target companies (TFC vs TNFC) and bidder companies (BFC vs BNFC) are reported at the bottom of the table along with their statistical significance.

Panel A. Premium (\%)

\begin{tabular}{|c|c|c|c|c|c|}
\hline & Composite I Index & Composite II Index & Payout Ratio & $\mathbf{K Z}$ & HP \\
\hline \multirow[t]{2}{*}{ TFC } & $9.585 * * *$ & $8.507^{* *}$ & 2.653 & $7.622 * * *$ & 4.474 \\
\hline & [0.007] & {$[0.012]$} & {$[0.345]$} & [0.005] & {$[0.329]$} \\
\hline \multirow[t]{2}{*}{ TNFC } & $-9.786 * * *$ & -3.540 & $-7.503 * *$ & $-6.333 * * *$ & $-5.166 * *$ \\
\hline & {$[0.000]$} & {$[0.176]$} & {$[0.013]$} & [0.010] & {$[0.037]$} \\
\hline \multirow[t]{2}{*}{$\mathrm{BFC}$} & 6.835 & 0.805 & -1.292 & 4.664 & 9.985 \\
\hline & {$[0.254]$} & {$[0.878]$} & [0.681] & {$[0.133]$} & [0.164] \\
\hline \multirow[t]{2}{*}{ BNFC } & 3.250 & 0.308 & -1.822 & $-3.983 *$ & 3.903 \\
\hline & {$[0.207]$} & {$[0.923]$} & {$[0.538]$} & {$[0.081]$} & {$[0.162]$} \\
\hline \multirow[t]{2}{*}{ Diversifying } & $-4.635 * *$ & $-5.945 * *$ & $-5.337 * *$ & $-4.989 * *$ & $-6.548 * * *$ \\
\hline & [0.039] & {$[0.015]$} & {$[0.024]$} & {$[0.017]$} & [0.002] \\
\hline \multirow[t]{2}{*}{ Hostile } & $7.762 * *$ & $9.084 * *$ & $7.255^{*}$ & 5.701 & $7.219 *$ \\
\hline & {$[0.045]$} & {$[0.027]$} & [0.069] & [0.119] & {$[0.052]$} \\
\hline \multirow[t]{2}{*}{ Tender Offer } & $9.603 * * *$ & $8.349 * * *$ & $10.811^{* * *}$ & $9.337 * * *$ & $10.023 * * *$ \\
\hline & {$[0.001]$} & {$[0.005]$} & {$[0.000]$} & {$[0.000]$} & [0.000] \\
\hline \multirow[t]{2}{*}{ Competition } & -4.608 & -4.369 & -5.087 & -2.726 & -2.944 \\
\hline & [0.242] & [0.293] & {$[0.218]$} & [0.484] & [0.452] \\
\hline \multirow[t]{2}{*}{ All in Cash } & $-23.381 * * *$ & $-24.593 * * *$ & $-23.713 * * *$ & $-21.052 * * *$ & $-24.075 * * *$ \\
\hline & [0.000] & {$[0.000]$} & [0.000] & {$[0.000]$} & [0.000] \\
\hline \multirow[t]{2}{*}{ All in Stock } & $-19.904 * * *$ & $-20.056^{* * *}$ & $-17.750 * * *$ & $-16.347 * * *$ & $-18.923 * * *$ \\
\hline & [0.000] & {$[0.000]$} & {$[0.000]$} & {$[0.000]$} & [0.000] \\
\hline \multirow[t]{2}{*}{ Relative Size } & $-1.779 * *$ & $-3.359 * * *$ & $-2.347 * * *$ & $-2.836 * * *$ & $-1.728 *$ \\
\hline & {$[0.034]$} & [0.000] & [0.006] & [0.000] & [0.059] \\
\hline \multirow[t]{2}{*}{ Recession } & 1.193 & 3.597 & 5.738 & 4.708 & 5.170 \\
\hline & [0.804] & {$[0.513]$} & {$[0.283]$} & {$[0.342]$} & {$[0.308]$} \\
\hline \multirow[t]{2}{*}{ T-Tobin's Q } & -1.553 & $-5.405 * * *$ & $-3.458 * * *$ & $-1.790 * *$ & $-1.938 * *$ \\
\hline & [0.149] & {$[0.000]$} & [0.002] & {$[0.046]$} & {$[0.038]$} \\
\hline \multirow[t]{2}{*}{ B-Tobin's Q } & $1.283^{* *}$ & $2.829 * * *$ & $2.003 * * *$ & $1.885^{* * *} *$ & $1.359 * *$ \\
\hline & {$[0.048]$} & {$[0.003]$} & [0.001] & [0.001] & [0.016] \\
\hline \multirow[t]{2}{*}{ T- FCF/TA } & $-8.609 * *$ & $-8.136^{*}$ & $-17.887 * * *$ & $-11.893 * * *$ & $-10.457 * * *$ \\
\hline & {$[0.035]$} & {$[0.088]$} & {$[0.000]$} & [0.001] & [0.003] \\
\hline \multirow[t]{2}{*}{ B- FCF/TA } & $8.841 * * *$ & 1.349 & $9.638 * * *$ & $5.501 *$ & $5.971 * *$ \\
\hline & [0.009] & [0.797] & [0.009] & {$[0.054]$} & [0.042] \\
\hline \multirow[t]{2}{*}{ Constant } & $77.469 * * *$ & $76.011 * * *$ & $66.434 * * *$ & $75.021 * * *$ & $82.181 * * *$ \\
\hline & {$[0.000]$} & {$[0.000]$} & {$[0.005]$} & {$[0.000]$} & {$[0.000]$} \\
\hline Diff (TFC - TNFC) & $19.371 * * *$ & $12.047 * * *$ & $10.156^{* * *}$ & $13.955^{* * *}$ & $9.64 * *$ \\
\hline Diff (BFC - BNFC) & 3.584 & 0.497 & 0.530 & $8.647 * * *$ & 6.082 \\
\hline Adj R-squared & 0.119 & 0.123 & 0.120 & 0.111 & 0.099 \\
\hline No of Deals & 1,582 & 1,388 & 1,414 & 1,757 & 1,731 \\
\hline
\end{tabular}


Table 4. Financial Constraints and Premiums and Announcement Returns: OLS analysis (Continued)

Panel B. Target 11-day CAR (\%)

\begin{tabular}{|c|c|c|c|c|c|}
\hline & Composite I Index & Composite II Index & Payout Ratio & $\mathbf{K Z}$ & HP \\
\hline \multirow[t]{2}{*}{ TFC } & $6.361 * * *$ & $4.673^{* *}$ & 0.717 & -1.662 & -0.845 \\
\hline & {$[0.002]$} & {$[0.012]$} & {$[0.661]$} & {$[0.242]$} & {$[0.759]$} \\
\hline \multirow[t]{2}{*}{ TNFC } & $-2.656^{* *}$ & -0.692 & $-3.283 * *$ & $-4.481 * * *$ & $-3.006 * *$ \\
\hline & {$[0.028]$} & {$[0.602]$} & {$[0.043]$} & {$[0.001]$} & {$[0.021]$} \\
\hline \multirow[t]{2}{*}{$\mathrm{BFC}$} & -0.542 & $-4.435 * *$ & $-4.049 * *$ & 0.167 & 6.161 \\
\hline & {$[0.843]$} & {$[0.046]$} & {$[0.031]$} & [0.912] & [0.103] \\
\hline \multirow[t]{2}{*}{ BNFC } & $2.743^{* *}$ & 1.378 & -2.391 & 0.033 & 1.999 \\
\hline & {$[0.036]$} & [0.401] & {$[0.202]$} & [0.980] & {$[0.183]$} \\
\hline \multirow[t]{2}{*}{ Diversifying } & -1.753 & -1.323 & $-2.471 *$ & $-2.159 *$ & $-2.763 * *$ \\
\hline & {$[0.167]$} & {$[0.330]$} & {$[0.079]$} & {$[0.071]$} & {$[0.024]$} \\
\hline \multirow[t]{2}{*}{ Hostile } & $4.773 * *$ & $4.981 * *$ & $5.644 * * *$ & $4.123 * *$ & $4.928 * * *$ \\
\hline & {$[0.012]$} & {$[0.011]$} & {$[0.004]$} & {$[0.027]$} & [0.009] \\
\hline \multirow[t]{2}{*}{ Tender Offer } & $7.114 * * *$ & $4.801 * * *$ & $6.101 * * *$ & $7.220 * * *$ & $7.522 * * *$ \\
\hline & {$[0.000]$} & {$[0.006]$} & {$[0.001]$} & {$[0.000]$} & {$[0.000]$} \\
\hline \multirow[t]{2}{*}{ Competition } & $-8.137 * * *$ & $-7.811 * * *$ & $-8.828 * * *$ & $-7.617 * * *$ & $-7.211 * * *$ \\
\hline & {$[0.000]$} & {$[0.000]$} & {$[0.000]$} & {$[0.000]$} & {$[0.000]$} \\
\hline \multirow[t]{2}{*}{ All in Cash } & $6.899 * * *$ & $5.880 * * *$ & $6.160 * * *$ & $6.716^{* * *}$ & $5.844 * * *$ \\
\hline & {$[0.000]$} & {$[0.001]$} & {$[0.001]$} & {$[0.000]$} & {$[0.001]$} \\
\hline \multirow[t]{2}{*}{ All in Stock } & $-2.383^{*}$ & $-2.707 * *$ & $-2.348^{*}$ & -1.902 & $-2.405^{*}$ \\
\hline & {$[0.062]$} & {$[0.048]$} & {$[0.100]$} & {$[0.128]$} & {$[0.052]$} \\
\hline \multirow[t]{2}{*}{ Relative Size } & $-2.274 * * *$ & $-3.076 * * *$ & $-3.037 * * *$ & $-2.790 * * *$ & $-2.476^{* * *}$ \\
\hline & {$[0.000]$} & {$[0.000]$} & {$[0.000]$} & {$[0.000]$} & {$[0.000]$} \\
\hline \multirow[t]{2}{*}{ Recession } & 5.101 & $8.617^{* *}$ & $9.038^{* *}$ & $5.531^{*}$ & $5.015^{*}$ \\
\hline & {$[0.114]$} & {$[0.029]$} & {$[0.032]$} & {$[0.068]$} & {$[0.088]$} \\
\hline \multirow[t]{2}{*}{ T-Tobin’s Q } & $-1.875^{* * *}$ & $-2.886^{* * *}$ & $-2.719 * * *$ & $-1.834 * * *$ & $-1.824 * * *$ \\
\hline & {$[0.003]$} & {$[0.000]$} & {$[0.000]$} & {$[0.000]$} & {$[0.000]$} \\
\hline \multirow[t]{2}{*}{ B-Tobin's Q } & $0.967 * * *$ & $1.418 * * *$ & $1.234 * * *$ & $1.274 * * *$ & $1.088 * * *$ \\
\hline & {$[0.010]$} & {$[0.004]$} & {$[0.000]$} & {$[0.000]$} & {$[0.000]$} \\
\hline \multirow[t]{2}{*}{ T- FCF/TA } & 3.100 & 3.029 & 2.114 & 1.452 & 1.919 \\
\hline & [0.125] & {$[0.140]$} & {$[0.266]$} & {$[0.474]$} & [0.332] \\
\hline \multirow[t]{2}{*}{ B- FCF/TA } & 0.547 & $-4.648 * *$ & -2.141 & 1.274 & 1.938 \\
\hline & [0.767] & {$[0.046]$} & {$[0.270]$} & {$[0.608]$} & {$[0.423]$} \\
\hline \multirow[t]{2}{*}{ Constant } & 7.627 & 8.792 & 11.079 & 10.899 & 12.095 \\
\hline & {$[0.369]$} & {$[0.247]$} & {$[0.257]$} & {$[0.183]$} & {$[0.126]$} \\
\hline Diff (TFC - TNFC) & $9.017 * * *$ & $5.365^{* * *}$ & $4.000 * * *$ & $2.819^{*}$ & 2.161 \\
\hline Diff (BFC - BNFC) & -3.285 & $-5.813 * * *$ & -1.658 & 0.134 & 4.162 \\
\hline Adj R-squared & 0.141 & 0.147 & 0.143 & 0.128 & 0.125 \\
\hline No of Deals & 1,751 & 1,440 & 1,447 & 1,947 & 1,925 \\
\hline
\end{tabular}


Table 4. Financial Constraints and Premiums and Announcement Returns: OLS analysis (Continued)

Panel C. Bidder 11-day CAR (\%)

\begin{tabular}{|c|c|c|c|c|c|}
\hline & Composite I Index & Composite II Index & Payout Ratio & $\mathbf{K Z}$ & HP \\
\hline \multirow[t]{2}{*}{ TFC } & $2.219 * * *$ & $1.465^{*}$ & 0.181 & 0.151 & $2.878 * * *$ \\
\hline & {$[0.005]$} & {$[0.054]$} & [0.787] & [0.813] & {$[0.008]$} \\
\hline \multirow[t]{2}{*}{ TNFC } & 0.121 & -0.174 & 0.135 & $-1.173 *$ & -0.715 \\
\hline & [0.834] & {$[0.771]$} & {$[0.852]$} & {$[0.070]$} & [0.205] \\
\hline \multirow[t]{2}{*}{$\mathrm{BFC}$} & 0.704 & 1.507 & 0.909 & 1.062 & 2.907 \\
\hline & {$[0.703]$} & [0.296] & {$[0.202]$} & {$[0.221]$} & [0.137] \\
\hline \multirow[t]{2}{*}{ BNFC } & $-1.275^{* *}$ & -0.705 & -0.114 & $-0.978^{*}$ & 0.203 \\
\hline & {$[0.038]$} & {$[0.310]$} & {$[0.854]$} & {$[0.080]$} & {$[0.768]$} \\
\hline \multirow[t]{2}{*}{ Diversifying } & -0.103 & -0.513 & 0.113 & -0.155 & -0.402 \\
\hline & [0.849] & {$[0.371]$} & [0.835] & {$[0.771]$} & {$[0.444]$} \\
\hline \multirow[t]{2}{*}{ Hostile } & -0.758 & -0.676 & -0.850 & -0.557 & -0.347 \\
\hline & [0.281] & {$[0.337]$} & {$[0.250]$} & [0.429] & {$[0.625]$} \\
\hline \multirow[t]{2}{*}{ Tender Offer } & 0.335 & 0.541 & 0.315 & 0.587 & 0.622 \\
\hline & {$[0.580]$} & [0.397] & [0.609] & {$[0.315]$} & {$[0.292]$} \\
\hline \multirow[t]{2}{*}{ Competition } & -1.302 & $-1.441^{*}$ & -0.754 & -1.518 & -1.424 \\
\hline & {$[0.148]$} & {$[0.073]$} & [0.410] & {$[0.115]$} & [0.133] \\
\hline \multirow[t]{2}{*}{ All in Cash } & $1.534 * *$ & $1.526 * *$ & $1.357 * *$ & $1.966 * * *$ & $1.705 * * *$ \\
\hline & {$[0.017]$} & {$[0.026]$} & {$[0.040]$} & [0.002] & {$[0.007]$} \\
\hline \multirow[t]{2}{*}{ All in Stock } & -0.939 & $-1.220^{*}$ & -0.291 & -0.149 & -0.809 \\
\hline & {$[0.158]$} & {$[0.074]$} & [0.667] & {$[0.825]$} & {$[0.228]$} \\
\hline \multirow[t]{2}{*}{ Relative Size } & -0.027 & -0.011 & -0.095 & -0.031 & 0.087 \\
\hline & [0.889] & {$[0.956]$} & {$[0.621]$} & {$[0.862]$} & {$[0.675]$} \\
\hline \multirow[t]{2}{*}{ Recession } & -0.123 & 0.031 & 0.304 & 0.761 & 0.841 \\
\hline & [0.947] & {$[0.987]$} & [0.885] & [0.707] & [0.685] \\
\hline \multirow[t]{2}{*}{ T-Tobin’s Q } & -0.383 & $-0.807 * *$ & -0.301 & -0.259 & -0.279 \\
\hline & {$[0.113]$} & {$[0.035]$} & [0.209] & {$[0.166]$} & [0.149] \\
\hline \multirow[t]{2}{*}{ B-Tobin's Q } & $-0.456 * *$ & -0.349 & $-0.372 *$ & $-0.381 * *$ & $-0.493 * * *$ \\
\hline & {$[0.015]$} & {$[0.163]$} & {$[0.060]$} & {$[0.016]$} & [0.002] \\
\hline \multirow[t]{2}{*}{$\mathrm{T}-\mathrm{FCF} / \mathrm{TA}$} & 2.221 & $3.142 *$ & -0.056 & 0.743 & 1.237 \\
\hline & [0.142] & {$[0.052]$} & {$[0.970]$} & {$[0.600]$} & {$[0.365]$} \\
\hline \multirow[t]{2}{*}{ B- FCF/TA } & -2.406 & $-5.491 * * *$ & -0.917 & -0.962 & -0.826 \\
\hline & [0.132] & {$[0.002]$} & [0.551] & {$[0.516]$} & {$[0.556]$} \\
\hline \multirow[t]{2}{*}{ Constant } & 0.292 & -0.975 & -2.138 & -0.150 & -0.704 \\
\hline & {$[0.898]$} & {$[0.743]$} & {$[0.449]$} & {$[0.950]$} & {$[0.759]$} \\
\hline Diff (TFC - TNFC) & $2.098^{* *}$ & $1.639 * *$ & 0.046 & $1.324 *$ & $3.593 * * *$ \\
\hline Diff (BFC - BNFC) & 1.979 & 2.212 & 1.023 & $2.040 * *$ & 2.704 \\
\hline Adj R-squared & 0.062 & 0.064 & 0.038 & 0.053 & 0.058 \\
\hline No of Deals & 1,637 & 1,560 & 1,447 & 1,815 & 1,797 \\
\hline
\end{tabular}


Table 4. Financial Constraints and Premiums and Announcement Returns: OLS analysis (Continued)

Panel D. Bidder AR (\$mil)

\begin{tabular}{|c|c|c|c|c|c|}
\hline & Composite I Index & Composite II Index & Payout Ratio & $\mathbf{K Z}$ & HP \\
\hline \multirow[t]{2}{*}{ TFC } & 21.493 & 47.830 & 59.907 & 22.312 & 17.645 \\
\hline & {$[0.540]$} & {$[0.227]$} & [0.239] & {$[0.559]$} & {$[0.662]$} \\
\hline \multirow[t]{2}{*}{ TNFC } & $-169.711 * *$ & $-142.391 * *$ & -95.299 & $-142.995^{*}$ & $-200.015^{* * *}$ \\
\hline & [0.014] & {$[0.025]$} & {$[0.391]$} & {$[0.078]$} & [0.002] \\
\hline \multirow[t]{2}{*}{$\mathrm{BFC}$} & $88.676 * *$ & 4.535 & 40.384 & 43.967 & 25.105 \\
\hline & {$[0.044]$} & {$[0.898]$} & {$[0.257]$} & [0.162] & {$[0.732]$} \\
\hline \multirow[t]{2}{*}{ BNFC } & $-114.667 * *$ & $-161.167 * * *$ & -126.741 & -21.220 & $-103.821^{*}$ \\
\hline & [0.035] & [0.004] & {$[0.103]$} & {$[0.729]$} & {$[0.095]$} \\
\hline \multirow[t]{2}{*}{ Diversifying } & 42.767 & 22.869 & -13.417 & 27.267 & 18.257 \\
\hline & {$[0.478]$} & {$[0.710]$} & {$[0.818]$} & {$[0.602]$} & {$[0.736]$} \\
\hline \multirow[t]{2}{*}{ Hostile } & -68.609 & -44.079 & -59.952 & -80.112 & -38.791 \\
\hline & [0.299] & {$[0.478]$} & {$[0.375]$} & [0.195] & {$[0.525]$} \\
\hline \multirow[t]{2}{*}{ Tender Offer } & 14.001 & 26.310 & -7.460 & -12.306 & 8.904 \\
\hline & {$[0.727]$} & {$[0.536]$} & [0.857] & {$[0.760]$} & {$[0.820]$} \\
\hline \multirow[t]{2}{*}{ Competition } & 29.435 & 10.122 & 59.610 & 14.076 & 30.258 \\
\hline & {$[0.644]$} & {$[0.870]$} & {$[0.342]$} & {$[0.815]$} & [0.619] \\
\hline \multirow[t]{2}{*}{ All in Cash } & 1.286 & -30.474 & -40.663 & 11.920 & -36.678 \\
\hline & {$[0.974]$} & {$[0.477]$} & {$[0.288]$} & {$[0.768]$} & [0.342] \\
\hline \multirow[t]{2}{*}{ All in Stock } & $-129.812 *$ & -140.426 & -106.785 & -73.176 & $-154.167 * *$ \\
\hline & {$[0.090]$} & {$[0.100]$} & {$[0.202]$} & {$[0.217]$} & [0.035] \\
\hline \multirow[t]{2}{*}{ Relative Size } & -35.184 & -37.581 & $-59.150 * *$ & -22.981 & -20.273 \\
\hline & [0.199] & {$[0.175]$} & {$[0.020]$} & {$[0.273]$} & {$[0.494]$} \\
\hline \multirow[t]{2}{*}{ Recession } & -169.958 & $-329.783^{*}$ & -207.822 & -166.939 & -44.871 \\
\hline & {$[0.214]$} & {$[0.066]$} & {$[0.229]$} & {$[0.190]$} & {$[0.418]$} \\
\hline \multirow[t]{2}{*}{ B-Tobin's Q } & -38.003 & -45.597 & $-85.083^{*}$ & -35.430 & -40.627 \\
\hline & {$[0.326]$} & {$[0.111]$} & {$[0.069]$} & {$[0.251]$} & [0.204] \\
\hline \multirow[t]{2}{*}{ T-Tobin's Q } & -29.852 & $-60.141^{*}$ & -14.473 & -21.304 & -25.994 \\
\hline & {$[0.234]$} & {$[0.100]$} & {$[0.569]$} & {$[0.226]$} & [0.151] \\
\hline \multirow[t]{2}{*}{ B- FCF/TA } & $92.892 * *$ & 82.868 & 53.088 & -18.504 & $58.245^{*}$ \\
\hline & {$[0.029]$} & {$[0.218]$} & [0.328] & {$[0.713]$} & {$[0.098]$} \\
\hline \multirow[t]{2}{*}{ T- FCF/TA } & $-112.559 *$ & $-220.628 *$ & $-175.532 * * *$ & $-129.636^{* *}$ & $-97.026^{*}$ \\
\hline & {$[0.072]$} & {$[0.070]$} & [0.009] & {$[0.021]$} & {$[0.069]$} \\
\hline \multirow[t]{2}{*}{ Constant } & 125.071 & $201.448^{*}$ & 35.419 & 39.395 & $211.483^{* *}$ \\
\hline & {$[0.198]$} & {$[0.092]$} & {$[0.782]$} & {$[0.670]$} & {$[0.023]$} \\
\hline Diff (TFC - TNFC) & $191.204^{* *}$ & $190.221 * * *$ & $155.206^{*}$ & $165.307 * *$ & $217.660 * * *$ \\
\hline Diff (BFC - BNFC) & $203.343 * * *$ & $165.702 * *$ & $167.125^{* *}$ & 65.187 & 128.926 \\
\hline Adj R-squared & 0.030 & 0.033 & 0.036 & 0.024 & 0.032 \\
\hline No of Deals & 1,637 & 1,560 & 1,447 & 1,815 & 1,797 \\
\hline
\end{tabular}


Table 5. Effects of Target's Financial Constraints on Premiums and Abnormal Returns: Propensity Score Matching

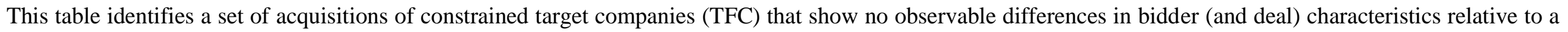

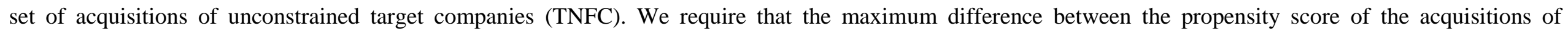

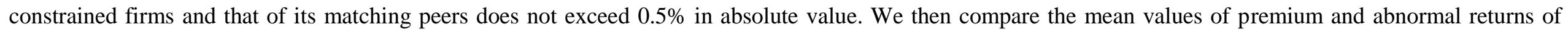
targets and bidders. Measures of financial constraints and definitions of all other variables are described in detail in the Appendix.

\begin{tabular}{|c|c|c|c|c|c|c|c|c|c|c|c|}
\hline & & \multicolumn{2}{|c|}{ Composite I Index } & \multicolumn{2}{|c|}{ Composite II Index } & \multicolumn{2}{|c|}{ Payout Ratio } & \multicolumn{2}{|c|}{$\mathbf{K Z}$} & \multicolumn{2}{|c|}{ HP } \\
\hline & & TFC & TNFC & TFC & TNFC & TFC & TNFC & TFC & TNFC & TFC & TNFC \\
\hline \multirow{4}{*}{ Premium (\%) } & Mean & 74.473 & 55.372 & 72.577 & 56.860 & 65.181 & 56.932 & 67.757 & 58.541 & 70.877 & 43.313 \\
\hline & Difference & & $19.100 * * *$ & & $15.717 * * *$ & & $8.249 * *$ & & $9.216^{* * *}$ & & $27.564 * *$ \\
\hline & & & {$[0.000]$} & & {$[0.000]$} & & {$[0.026]$} & & {$[0.051]$} & & {$[0.045]$} \\
\hline & No. of Obs. & & 106 & & 229 & & 288 & & 181 & & 13 \\
\hline \multirow{4}{*}{$\begin{array}{l}\text { Target } \\
\text { Abnormal } \\
\text { Return }(\%)\end{array}$} & Mean & 32.238 & 22.511 & 26.725 & 21.891 & 22.707 & 19.466 & 23.544 & 19.491 & 34.268 & 19.329 \\
\hline & Difference & & $9.728 * *$ & & $4.833 * *$ & & $3.241 *$ & & $4.054 *$ & & $14.938 * * *$ \\
\hline & & & {$[0.031]$} & & {$[0.043]$} & & {$[0.079]$} & & {$[0.082]$} & & [ 0.065$]$ \\
\hline & No. of Obs. & & 118 & & 247 & & 375 & & 254 & & 38 \\
\hline \multirow{4}{*}{$\begin{array}{l}\text { Bidder } \\
\text { Abnormal } \\
\text { Return }(\%)\end{array}$} & Mean & 1.875 & -0.825 & 0.889 & -0.893 & 0.095 & -1.540 & -0.482 & -2.477 & 4.156 & -0.010 \\
\hline & Difference & & $2.700 *$ & & $1.782 * *$ & & $1.635^{*}$ & & $1.995 * *$ & & $4.146^{*}$ \\
\hline & & & {$[0.091]$} & & {$[0.086]$} & & {$[0.091]$} & & {$[0.042]$} & & {$[0.060]$} \\
\hline & No. of Obs. & & 121 & & 174 & & 295 & & 255 & & 39 \\
\hline \multirow{4}{*}{$\begin{array}{l}\text { Bidder } \\
\text { Abnormal } \\
\text { Return (\$) }\end{array}$} & Mean & 39.834 & -188.509 & 41.591 & -118.829 & -64.620 & -215.082 & -24.184 & -114.293 & 4.135 & -547.379 \\
\hline & Difference & & $228.343 *$ & & $160.420 *$ & & 150.462 & & $90.109 *$ & & 551.514 \\
\hline & & & {$[0.055]$} & & [0.068] & & {$[0.173]$} & & {$[0.079]$} & & [0.107] \\
\hline & No. of Obs. & & 121 & & 174 & & 295 & & 255 & & 39 \\
\hline
\end{tabular}




\section{Table 6. Effects of Bidder's Financial Constraints on Premiums and Abnormal Returns: Propensity Score Matching}

This table identifies a set of acquisitions of constrained bidder companies (BFC) that show no observable differences in target (and deal) characteristics relative to a set of acquisitions of unconstrained bidder companies (BNFC). We require that the maximum difference between the propensity score of the acquisitions of constrained firms and that of its matching peers does not exceed $0.5 \%$ in absolute value. We then compare the mean values of premium and abnormal returns of targets and bidders. Measures of financial constraints and definitions of all other variables are described in detail in the Appendix.

\begin{tabular}{|c|c|c|c|c|c|c|c|c|c|c|c|}
\hline & & \multicolumn{2}{|c|}{ Composite I Index } & \multicolumn{2}{|c|}{ Composite II Index } & \multicolumn{2}{|c|}{ Payout Ratio } & \multicolumn{2}{|c|}{$\mathbf{K Z}$} & \multicolumn{2}{|c|}{ HP } \\
\hline & & $\mathrm{BFC}$ & BNFC & BFC & BNFC & $\mathrm{BFC}$ & BNFC & $\mathrm{BFC}$ & BNFC & $\mathrm{BFC}$ & BNFC \\
\hline \multirow{4}{*}{ Premium (\%) } & Mean & 80.828 & 63.372 & 70.202 & 64.993 & 60.904 & 62.083 & 72.439 & 64.452 & 72.053 & 67.192 \\
\hline & Difference & & 17.455 & & 5.209 & & -1.179 & & 7.98748 & & 4.862 \\
\hline & & & {$[0.118]$} & & {$[0.503]$} & & {$[0.720]$} & & {$[0.103]$} & & [0.912] \\
\hline & No. of Obs. & & 39 & & 76 & & 350 & & 185 & & 4 \\
\hline \multirow{2}{*}{$\begin{array}{l}\text { Target } \\
\text { Abnormal } \\
\text { Return (\%) }\end{array}$} & Mean & 16.386 & 24.310 & 16.094 & 20.758 & 20.356 & 21.979 & 20.067 & 22.864 & 20.972 & 14.617 \\
\hline & No. of Obs. & & 44 & & 98 & & 378 & & 217 & & 7 \\
\hline \multirow{4}{*}{$\begin{array}{l}\text { Bidder } \\
\text { Abnormal } \\
\text { Return }(\%)\end{array}$} & Mean & -0.277 & -0.825 & -0.704 & -2.294 & -0.001 & -1.226 & -1.526 & -0.036 & -11.110 & -1.823 \\
\hline & Difference & & 2.344 & & 1.590 & & 1.225 & & 1.490 & & -9.287 \\
\hline & & & [0.419] & & {$[0.382]$} & & [0.119] & & {$[0.243]$} & & [0.258] \\
\hline & No. of Obs. & & 43 & & 97 & & 389 & & 218 & & 7 \\
\hline $\begin{array}{l}\text { Bidder } \\
\text { Abnormal } \\
\text { Return (\$) }\end{array}$ & No. of Obs. & & 43 & & 97 & & 389 & & 218 & & 7 \\
\hline
\end{tabular}




\section{Table 7. Summary Statistics of Target and Non-Target Companies' Characteristics}

This table presents mean (median) values of variables included in model (2) for two separate subsamples of target and non-target companies (firm-year observations). P-values of the differences in mean between the two subgroups are reported in the last column. Definitions of all variables are given in the Appendix.

\begin{tabular}{|c|c|c|c|c|c|}
\hline & \multicolumn{2}{|c|}{ Target Firms } & \multicolumn{2}{|c|}{$\begin{array}{c}\begin{array}{c}\text { Non-Target } \\
\text { Firms }\end{array} \\
\end{array}$} & \multirow[b]{2}{*}{ P-val } \\
\hline & Mean & Median & Mean & Median & \\
\hline Composite I Index & 3.361 & 3.500 & 3.223 & 3.333 & 0.000 \\
\hline Composite II Index & 3.641 & 3.750 & 3.494 & 3.500 & 0.000 \\
\hline Payout Ratio & 0.413 & 0.405 & 0.387 & 0.393 & 0.002 \\
\hline KZ Index & 3.680 & 3.671 & 3.619 & 3.648 & 0.000 \\
\hline HP Index & 4.375 & 4.383 & 4.382 & 4.423 & 0.211 \\
\hline Average Excess Return (\%) & 0.094 & 0.069 & 0.092 & 0.070 & 0.589 \\
\hline Growth-Resource Imbalance & 0.312 & 0.000 & 0.311 & 0.000 & 0.800 \\
\hline Average Sales Growth (\%) & 17.124 & 7.846 & 17.080 & 8.348 & 0.950 \\
\hline Average Liquid Assets (\%) & 26.354 & 24.053 & 26.924 & 24.280 & 0.052 \\
\hline Average PPE/TA (\%) & 30.121 & 24.712 & 29.715 & 23.892 & 0.211 \\
\hline Average Book Leverage (\%) & 37.210 & 30.114 & 34.553 & 24.514 & 0.000 \\
\hline Industry Dummy & 0.749 & 1.000 & 0.700 & 1.000 & 0.000 \\
\hline Size $(\$ m)$ & 1070 & 138 & 2100 & 179 & 0.000 \\
\hline Market to Book & 2.451 & 1.531 & 2.892 & 1.712 & 0.000 \\
\hline Price to Earnings & 17.684 & 9.712 & 18.664 & 11.667 & 0.058 \\
\hline Number of Observations & \multicolumn{2}{|c|}{5,090} & \multicolumn{2}{|c|}{76,443} & \\
\hline
\end{tabular}




\section{Table 8. Effects of Financial Constraints on takeover targets likelihood: Logit Results}

This table presents the results of logit estimates for model (2) where the dependent variable is a dummy equal to 1 if the firm was subject to an acquisition bid (for majority interest) during the specific year, and 0 otherwise. Measures of financial constraints and definitions of all other variables are described in detail in the Appendix. P-values are reported in brackets below each coefficient. Marginal effects are reported next to the corresponding coefficient.

Panel A. Base Model, Composite I Index and Composite II Index

\begin{tabular}{|c|c|c|c|c|c|c|}
\hline \multirow[b]{3}{*}{ Financial Constraints Measure } & \multicolumn{2}{|c|}{ Base Model } & \multicolumn{2}{|c|}{ Composite I Index } & \multicolumn{2}{|c|}{ Composite II Index } \\
\hline & Coeff. & M.E. & Coeff. & M.E. & Coeff. & M.E. \\
\hline & & & $\begin{array}{c}0.066 * * * \\
{[0.001]}\end{array}$ & 0.202 & $\begin{array}{c}0.051 * * * \\
{[0.008]}\end{array}$ & 0.170 \\
\hline Average Excess Return (\%) & $\begin{array}{c}0.018 \\
{[0.754]}\end{array}$ & 0.002 & $\begin{array}{c}-0.042 \\
{[0.512]}\end{array}$ & -0.004 & $\begin{array}{c}-0.005 \\
{[0.947]}\end{array}$ & 0.000 \\
\hline Growth-Resource Imbalance & $\begin{array}{c}0.096 * * * \\
{[0.010]}\end{array}$ & 0.028 & $\begin{array}{c}0.033 \\
{[0.426]}\end{array}$ & 0.009 & $\begin{array}{c}0.009 \\
{[0.847]}\end{array}$ & 0.002 \\
\hline Average Sales Growth (\%) & $\begin{array}{c}0.00013 \\
{[0.981]}\end{array}$ & 0.000 & $\begin{array}{c}0.00028 \\
{[0.701]}\end{array}$ & 0.002 & $\begin{array}{c}0.00023 \\
{[0.434]}\end{array}$ & 0.004 \\
\hline Average Liquid Assets (\%) & $\begin{array}{c}-0.005^{* * *} * \\
{[0.000]}\end{array}$ & -0.116 & $\begin{array}{c}-0.003 * * \\
{[0.017]}\end{array}$ & -0.062 & $\begin{array}{c}-0.002 * * \\
{[0.038]}\end{array}$ & -0.055 \\
\hline Average PPE/TA (\%) & $\begin{array}{c}-0.002 * * * \\
{[0.003]}\end{array}$ & -0.064 & $\begin{array}{c}-0.001 \\
{[0.152]}\end{array}$ & -0.037 & $\begin{array}{c}0.000 \\
{[0.598]}\end{array}$ & -0.015 \\
\hline Average Book Leverage (\%) & $\begin{array}{c}0.003 * * * \\
{[0.000]}\end{array}$ & 0.106 & $\begin{array}{c}0.003 * * * \\
{[0.000]}\end{array}$ & 0.105 & $\begin{array}{c}0.003 * * * \\
{[0.000]}\end{array}$ & 0.109 \\
\hline Industry Dummy & $\begin{array}{c}0.264 * * * \\
{[0.000]}\end{array}$ & 0.174 & $\begin{array}{c}0.285^{* * *} * \\
{[0.000]}\end{array}$ & 0.187 & $\begin{array}{c}0.288 * * * \\
{[0.000]}\end{array}$ & 0.186 \\
\hline Size $(\$ m)$ & $\begin{array}{c}-0.00004 * * * \\
{[0.000]}\end{array}$ & -0.102 & $\begin{array}{c}-0.00004^{* * *} * \\
{[0.000]}\end{array}$ & -0.088 & $\begin{array}{c}-0.00005^{* * *} \\
{[0.000]}\end{array}$ & -0.098 \\
\hline Market to Book & $\begin{array}{c}-0.024 * * * \\
{[0.000]}\end{array}$ & -0.065 & $\begin{array}{c}-0.017 * * * \\
{[0.000]}\end{array}$ & -0.045 & $\begin{array}{c}-0.017 * * * \\
{[0.000]}\end{array}$ & -0.045 \\
\hline Price to Earnings & $\begin{array}{c}0.00013 \\
{[0.399]}\end{array}$ & -0.006 & $\begin{array}{c}0.00004 \\
{[0.777]}\end{array}$ & 0.002 & $\begin{array}{c}-0.00021 \\
{[0.928]}\end{array}$ & 0.001 \\
\hline Constant & $\begin{array}{c}-2.710^{* * *} \\
{[0.000]}\end{array}$ & & $\begin{array}{c}-3.157 * * * \\
{[0.000]}\end{array}$ & & $\begin{array}{c}-3.146 * * * \\
{[0.000]}\end{array}$ & \\
\hline Log-likelihood & $-18,866.66$ & & $-15,640.67$ & & $-14,093.73$ & \\
\hline Pseudo R-squared & 0.009 & & 0.009 & & 0.009 & \\
\hline No. of Obs. & 81,533 & & 73,286 & & 65,989 & \\
\hline
\end{tabular}


Table 8. Effects of Financial Constraints

on takeover targets likelihood: Logit Results (Continued)

Panel B. Payout Ratio, KZ Index and HP Index

\begin{tabular}{|c|c|c|c|c|c|c|}
\hline \multirow[b]{2}{*}{ Financial Constraints Measure } & \multicolumn{2}{|c|}{ Payout Ratio } & \multicolumn{2}{|c|}{ KZ Index } & \multicolumn{2}{|c|}{ HP Index } \\
\hline & $\begin{array}{c}\text { Coeff. } \\
0.047^{*} \\
{[0.081]}\end{array}$ & $\frac{M . E .}{0.017}$ & $\begin{array}{c}\text { Coeff. } \\
1.051^{* * *} \\
{[0.000]}\end{array}$ & $\frac{\text { M.E. }}{3.606}$ & $\begin{array}{c}\text { Coeff. } \\
0.129 * * * \\
{[0.002]}\end{array}$ & $\frac{M . E .}{0.533}$ \\
\hline Average Excess Return (\%) & $\begin{array}{c}0.037 \\
{[0.562]}\end{array}$ & 0.003 & $\begin{array}{c}0.023 \\
{[0.712]}\end{array}$ & 0.002 & $\begin{array}{c}0.017 \\
{[0.773]}\end{array}$ & 0.001 \\
\hline Growth-Resource Imbalance & $\begin{array}{l}0.077 * \\
{[0.060]}\end{array}$ & 0.023 & $\begin{array}{c}0.103 * * * \\
{[0.010]}\end{array}$ & 0.031 & $\begin{array}{c}0.104 * * * \\
{[0.005]}\end{array}$ & 0.031 \\
\hline Average Sales Growth (\%) & $\begin{array}{c}0.00039 \\
{[0.493]}\end{array}$ & 0.003 & $\begin{array}{c}0.00012 \\
{[0.213]}\end{array}$ & 0.006 & $\begin{array}{c}0.00001 \\
{[0.693]}\end{array}$ & 0.002 \\
\hline Average Liquid Assets (\%) & $\begin{array}{c}-0.003 * * * \\
{[0.002]}\end{array}$ & -0.084 & $\begin{array}{l}-0.001 \\
{[0.305]}\end{array}$ & -0.028 & $\begin{array}{c}-0.005 * * * \\
{[0.000]}\end{array}$ & -0.126 \\
\hline Average PPE/TA (\%) & $\begin{array}{c}-0.002 * * \\
{[0.025]}\end{array}$ & -0.056 & $\begin{array}{c}-0.003 * * * \\
{[0.000]}\end{array}$ & -0.091 & $\begin{array}{c}-0.003 * * * \\
{[0.001]}\end{array}$ & -0.078 \\
\hline Average Book Leverage (\%) & $\begin{array}{c}0.003 * * * \\
{[0.000]}\end{array}$ & 0.100 & $\begin{array}{c}0.003 * * * \\
{[0.000]}\end{array}$ & 0.084 & $\begin{array}{c}0.003 * * * \\
{[0.000]}\end{array}$ & 0.093 \\
\hline Industry Dummy & $\begin{array}{c}0.294 * * * \\
{[0.000]}\end{array}$ & 0.194 & $\begin{array}{c}0.372 * * * \\
{[0.000]}\end{array}$ & 0.248 & $\begin{array}{c}0.278^{* * *} \\
{[0.000]}\end{array}$ & 0.185 \\
\hline Size $(\$ m)$ & $\begin{array}{c}-0.00004 * * * \\
{[0.000]}\end{array}$ & -0.098 & $\begin{array}{c}-0.00006 * * * \\
{[0.000]}\end{array}$ & -0.082 & $\begin{array}{c}-0.00005^{* * *} \\
{[0.000]}\end{array}$ & -0.108 \\
\hline Market to Book & $\begin{array}{c}-0.021 * * * \\
{[0.000]}\end{array}$ & -0.055 & $\begin{array}{c}-0.018 * * * \\
{[0.000]}\end{array}$ & -0.050 & $\begin{array}{c}-0.026 * * * \\
{[0.000]}\end{array}$ & -0.069 \\
\hline Price to Earnings & $\begin{array}{c}0.00007 \\
{[0.662]}\end{array}$ & -0.004 & $\begin{array}{c}-0.00034 \\
{[0.876]}\end{array}$ & 0.001 & $\begin{array}{c}-0.00037 \\
{[0.446]}\end{array}$ & -0.006 \\
\hline Constant & $\begin{array}{c}-2.918^{* * *} \\
{[0.000]}\end{array}$ & & $\begin{array}{c}-6.827 * * * \\
{[0.000]}\end{array}$ & & $\begin{array}{c}-3.252 * * * \\
{[0.000]}\end{array}$ & \\
\hline Log-likelihood & $-15,722.93$ & & $-16,505.10$ & & $-18,213.73$ & \\
\hline Pseudo R-squared & 0.009 & & 0.015 & & 0.010 & \\
\hline No. of Obs. & 73,640 & & 77,451 & & 79,103 & \\
\hline
\end{tabular}




\section{Appendix. Variables Definitions}

\begin{tabular}{|c|c|}
\hline Variable & Definition \\
\hline \multicolumn{2}{|r|}{ Financial Constraints measures } \\
\hline Composite I Index & $\begin{array}{l}\text { All firms in COMPUSTAT are sorted based on dividend payout } \\
\text { ratio, size, interest coverage ratio, and the } K Z \text { index separately. } \\
\text { (Please see below for the definitions of each of these variables). } \\
\text { Companies are then ranked in quintiles and assigned a score of } 1 \\
\text { to } 5 \text { for each distribution. Further, a score of } 0 \text { (5) to is assigned to } \\
\text { those companies without (with) commercial paper rating and } \\
\text { bond rating separately. A company is required to have at least } \\
\text { three of the above six criteria available. Further, an overall score } \\
\text { is assigned to each firm based on the weighted average ranks } \\
\text { (weights are based on the number of available components). The } \\
\text { lower the overall score the higher the financial constraints. } \\
\text { Therefore, to make the interpretation of results more intuitive, the } \\
\text { overall ranking is transformed as " } 6 \text {-overall ranking", so that the } \\
\text { higher the overall ranking, the more constrained the company. } \\
\text { Finally, firms in the top (bottom) three deciles of the overall rank } \\
\text { distribution are assigned to the financially constrained } \\
\text { (unconstrained) group. }\end{array}$ \\
\hline Composite II Index & $\begin{array}{l}\text { The definition of this index is similar to Composite I Index one. The } \\
\text { only difference is that it excludes } K Z \text { index and size from the rankings. }\end{array}$ \\
\hline Payout Ratio & $\begin{array}{l}\text { Following Hubbard and Palia (1999), Dividend payout ratio is defined } \\
\text { as the two-year average of the dividend payout ratio from the two } \\
\text { preceding annual reports at each point in time. Payout ratio is defined as } \\
\text { the sum of dividends (DVP and DVC) plus stock repurchases (total } \\
\text { expenditure on the purchase of common and preferred stocks } \\
\text { (PRSTKC) minus any reduction in the value of the net number of } \\
\text { preferred stocks outstanding (redemption value, PSTKRV) divided by } \\
\text { operating income as in Jagannathan, Stephens and Weisbach (2000). } \\
\text { In line with Hadlock and Pierce (2010), payout ratio is set equal to } 1 \text { if it } \\
\text { is above } 1 \text { or if a firm has negative operating income and positive } \\
\text { dividends. } \\
\text { After computing the two-year average payout ratios for all companies on } \\
\text { COMPUSTAT, we rank the companies based on this measure and } \\
\text { rescale the rankings to the [0,5] interval with } 5 \text { representing the most } \\
\text { constrained companies (with the lowest payout ratios) to be in line with } \\
\text { the previously described measures. The firms in the top (bottom) three } \\
\text { deciles of the rescaled index are then assigned to the financially } \\
\text { constrained (unconstrained) group. }\end{array}$ \\
\hline KZ Index & $\begin{array}{l}\text { In line with Lamont, Polk, and Saa-Requejo }(2001) \text { : } \\
K Z=-1.002 \times \text { CashFlow }+0.283 \times \text { Tobin'sQ }+3.139 \times \text { Leverage } \\
-39.368 \times \text { Dividends }-1.315 \times \text { CashHolding } \\
\text { where CashFlow is the firm's cash flow }(\mathrm{IB}+\mathrm{DP}) \text { normalized by the } \\
\text { lagged value of property, plant and equipment }(\mathrm{lag} \text {. PPENT); Tobin's } Q \\
\text { is Tobin's Q ((AT-CEQ-TXDB+PRCC_C*CSHO)/ AT)), Leverage is }\end{array}$ \\
\hline
\end{tabular}




\begin{tabular}{|c|c|}
\hline & $\begin{array}{l}\text { total debt (DLTT+DLC) divided by total debt plus value of } \\
\text { stockholders' equity (DLTT+DLC+SEQ), Dividends is dividend } \\
\text { defined as total proceeds to ordinary and preferred stocks (DVP+DVC) } \\
\text { divided by the lagged value property, plant and equipment (lag. } \\
\text { PPENT); CashHolding is the firm's cash holding defined as cash and } \\
\text { short-term investments (CHE) divided by the lagged value of property, } \\
\text { plant and equipment (lag.PPENT). } \\
\text { After computing the } K Z \text { index for all companies on COMPUSTAT, we } \\
\text { rank the companies based on this measure and rescale the rankings to } \\
\text { the [0,5] interval with } 5 \text { representing the most constrained companies } \\
\text { (with the lowest KZ index) to be consistent with our other measures. } \\
\text { Firms in the top (bottom) three deciles of the rescaled index are then } \\
\text { assigned to the financially constrained (unconstrained) group. }\end{array}$ \\
\hline HP Index (FC Measure) & $\begin{array}{l}\text { In line with Hadlock and Pierce }(2010) \text { : } \\
\qquad H P=-0.737 \times \text { Size }+0.043 \times \text { Size }^{2}-0.040 \times \text { Age } \\
\text { where Size the logarithm of inflation-adjusted book value of assets (AT) } \\
\text { and Age is the length of time (in years) since the firm had first a non- } \\
\text { missing stock price on COMPUSTAT. } \\
\text { Following Hadlock and Pierce (2010), we winsorize Size at (the log of) } \\
\$ 4.5 \text { billion and Age at } 37 \text { years. Furthermore, size is inflation adjusted } \\
\text { to } 2004 \text { CPI level. After computing the HP index for all companies on } \\
\text { COMPUSTAT, we rank the companies based on this measure and } \\
\text { rescale the rankings to the [0,5] interval with } 5 \text { representing the most } \\
\text { constrained companies (with the lowest HP index) to be in line with the } \\
\text { previously described measures. Firms in the top (bottom) three deciles } \\
\text { of the rescaled index are then assigned to the financially constrained } \\
\text { (unconstrained) group. }\end{array}$ \\
\hline \multicolumn{2}{|r|}{ Other variables } \\
\hline Premium & $\begin{array}{l}\text { From Officer (2003): "The aggregate amount of each form of payment } \\
\text { offered to target shareholders (cash, equity, debt, etc.)" divided by the } \\
\text { market value of the target (or the sought stake) } 43 \text { days prior to the bid } \\
\text { announcement if the result falls between } 0 \text { and } 2 . \text { If not, "the final (and } \\
\text { then the initial) price per share of target stock offered by the bidder" } \\
\text { divided by the target share price } 43 \text { days before the announcement if this } \\
\text { number falls between } 0 \text { and } 2 \text {. Missing if neither of the above conditions } \\
\text { is met. }\end{array}$ \\
\hline Target 11-day CAR (\%) & $\begin{array}{l}\text { Cumulative target percentage abnormal return in a }[-5,+5] \text { day period } \\
\text { surrounding acquisition announcement. }\end{array}$ \\
\hline Bidder 11-day CAR (\%) & $\begin{array}{l}\text { Cumulative bidder percentage abnormal return in a }[-5,+5] \text { day period } \\
\text { surrounding acquisition announcement. }\end{array}$ \\
\hline Bidder AR (\$mil) & $\begin{array}{l}\text { Cumulative bidder dollar abnormal return in a }[-5,+5] \text { day period } \\
\text { surrounding acquisition announcement. }\end{array}$ \\
\hline Total Assets (\$m) & Total Assets (AT). \\
\hline Sales $(\$ m)$ & Total Sales (SALE). \\
\hline Cost of Debt & $\begin{array}{l}\text { Cost of Debt, next year's Interest Expense divided by average of this } \\
\text { year and next year's Total Debt; }(2 * \text { F. XINT / (DLTT + DLC + F. } \\
\text { DLTT + F. DLC) }) \text {. }\end{array}$ \\
\hline Coverage Ratio & $\begin{array}{l}\text { Interest Coverage Ratio; Operating Income before Depreciation divided } \\
\text { by Interest Expense (OIBDP / XINT). }\end{array}$ \\
\hline
\end{tabular}




\begin{tabular}{|c|c|}
\hline Total Debt/MVE & $\begin{array}{l}\text { Total Debt divided by Market Value of Equity; Sum of Long-Term Debt } \\
\text { and Debt in Current Liabilities divided by Common Shares Outstanding } \\
\text { times Price ((DLTT + DLC)/(CSHO * PRCC_C)). }\end{array}$ \\
\hline Tobin's $Q$ & $\begin{array}{l}\text { Tobin's Q; Total Assets minus Common Equity minus Deferred Taxes } \\
\text { plus Shares Outstanding times Price divided by Total Assets (AT - CEQ } \\
\text { - TXDB + CSHO * PRCC_C) / AT). From Hadlock and Pierce (2010). }\end{array}$ \\
\hline Cash Holding/PPE & $\begin{array}{l}\text { Cash Holding; Cash and Short-Term Investments divided by lagged } \\
\text { value of Property, Plant and Equipment (CHE /lag.PPENT). From } \\
\text { Hadlock and Pierce (2010). }\end{array}$ \\
\hline CapEx/TA & $\begin{array}{l}\text { Capital Expenditure normalized by Total Assets; Capital Expenditure } \\
\text { divided by lagged value of Total Assets (CAPX /lag.AT). }\end{array}$ \\
\hline PPE/TA (\%) & $\begin{array}{l}\text { Property, Plant and } \text { Equipment normalized by } \\
\text { (PPENT/AT). }\end{array}$ \\
\hline$F C F / B V A$ & $\begin{array}{l}\text { Free Cash Flows normalized by Total Assets; Operating Income Before } \\
\text { Depreciation minus 'Total Income Taxes minus Change in Deferred } \\
\text { Taxes' minus Gross Interest Expense minus Preferred Dividends Minus } \\
\text { Common Dividends, divided by Total Assets (AT - (TXT - TXDITC + } \\
\text { lag.TXDITC) - XINT - DVP - DVC). }\end{array}$ \\
\hline Trans. Value $(\$ m)$ & Value of Transaction in \$ million from SDC. \\
\hline Diversifying & Dummy equal to 1 if bidder and target have different 2-digit SIC codes. \\
\hline Hostile & Dummy equal to 1 if SDC reports the acquisition to be hostile. \\
\hline Tender Offer & Dummy equal to 1 if SDC reports the acquisition to involve tender offer. \\
\hline Competition & $\begin{array}{l}\text { Dummy equal to } 1 \text { if SDC reports the acquisition to involve competition } \\
\text { among bidders. }\end{array}$ \\
\hline All in Cash & $\begin{array}{l}\text { Dummy equal to } 1 \text { if SDC reports the acquisition to be fully settled in } \\
\text { cash. }\end{array}$ \\
\hline All in Stock & $\begin{array}{l}\text { Dummy equal to } 1 \text { if SDC reports the acquisition to be fully settled in } \\
\text { stocks. }\end{array}$ \\
\hline Relative Size & Natural logarithm of target total assets divided by bidder total assets. \\
\hline Recession & $\begin{array}{l}\text { Dummy equal to } 1 \text { if the acquisition is announced during the following } \\
\text { recessionary periods: } 1 \text { Jan } 1980 \text { to } 1 \text { Aug } 1980 ; 1 \mathrm{Jul} 1981 \text { to } 1 \text { Dec } \\
\text { 1982; } 1 \text { Jul } 1990 \text { to } 1 \text { Apr } 1991 ; 1 \text { Mar } 2001 \text { to } 1 \text { Dec } 2001 ; 1 \text { Dec } 2007 \\
\text { to the end of sample period. }\end{array}$ \\
\hline Average Excess Return (\%) & $\begin{array}{l}\text { Average daily excess return (\%) of company } i \text { estimated over the four } \\
\text { calendar years prior the acquisition, where the market model parameters } \\
\text { are computed using data from the fifth year prior to acquisition } \\
\text { announcement. From Palepu (1986). }\end{array}$ \\
\hline Growth-Resource Imbalance & $\begin{array}{l}\text { Dummy equal to } 1 \text { if the firm has a combination of either low growth- } \\
\text { high liquidity-low leverage or high growth-low liquidity-high leverage, } \\
\text { and } 0 \text { otherwise, where high and low are defined with respect to the } \\
\text { corresponding average value of all (non-financial/non-regulated) } \\
\text { COMPUSTAT firms. From Palepu (1986). }\end{array}$ \\
\hline Average Sales Growth (\%) & $\begin{array}{l}\text { Annual percentage growth in Total Sales (SALE) averaged over the } \\
\text { three fiscal years prior to acquisition announcement. From Palepu } \\
\text { (1986). }\end{array}$ \\
\hline
\end{tabular}




\begin{tabular}{|c|c|}
\hline Average Liquid Assets (\%) & $\begin{array}{l}\text { Ratio of Net Liquid Assets (CHE + RECT) divided by Total Assets } \\
\text { (AT) averaged over the three fiscal years prior to acquisition } \\
\text { announcement. From Palepu (1986). }\end{array}$ \\
\hline Average Book Leverage (\%) & $\begin{array}{l}\text { Ratio of Long-Term Debt (DLTT) divided by the sum of Preferred and } \\
\text { Common Equity (PSTKL + CEQT) averaged over the three fiscal years } \\
\text { prior to acquisition announcement. From Palepu (1986). }\end{array}$ \\
\hline Industry Dummy & $\begin{array}{l}\text { Dummy equal to } 1 \text { if there has been any acquisition attempt in the firm's } \\
\text { 4-digit SIC code during the fiscal year prior to acquisition } \\
\text { announcement. From Palepu (1986). }\end{array}$ \\
\hline Size & Total Assets in \$m (AT). \\
\hline Market to Book & $\begin{array}{l}\text { Ratio of the market value of the common equity (PRCC_C } * \text { CSHO) to } \\
\text { the book value of equity (CEQ). From Palepu (1986). }\end{array}$ \\
\hline Price to Earnings & $\begin{array}{l}\text { Ratio of Stock Price Per Share (PRCC_C) to Earnings Per Share } \\
\text { (EPSPX). From Palepu (1986). }\end{array}$ \\
\hline Average PPE/TA (\%) & $\begin{array}{l}\text { Ratio of Plant, Property and Equipment (PPENT) divided by Total } \\
\text { Assets (AT) averaged over the three fiscal years prior to acquisition } \\
\text { announcement. From Billett and Xue (2007)). }\end{array}$ \\
\hline
\end{tabular}

